\title{
Molecular Plasticity of the Nucleus Accumbens Revisited-Astrocytic Waves Shall Rise
}

\author{
Julianna Kardos ${ }^{1}$ (D) - Árpád Dobolyi ${ }^{2,3} \cdot$ Zsolt Szabó $^{1}$ • Ágnes Simon ${ }^{1} \cdot$ Guillaume Lourmet $^{2} \cdot$ Miklós Palkovits $^{4}$. \\ László Héja ${ }^{1}$
}

Received: 18 October 2018 / Accepted: 6 May 2019 / Published online: 27 May 2019

(C) The Author(s) 2019

\begin{abstract}
Part of the ventral striatal division, the nucleus accumbens (NAc) drives the circuit activity of an entire macrosystem about reward like a "flagship," signaling and leading diverse conducts. Accordingly, NAc neurons feature complex inhibitory phenotypes that assemble to process circuit inputs and generate outputs by exploiting specific arrays of opposite and/or parallel neurotransmitters, neuromodulatory peptides. The resulting complex combinations enable versatile yet specific forms of accumbal circuit plasticity, including maladaptive behaviors. Although reward signaling and behavior are elaborately linked to neuronal circuit activities, it is plausible to propose whether these neuronal ensembles and synaptic islands can be directly controlled by astrocytes, a powerful modulator of neuronal activity. Pioneering studies showed that astrocytes in the NAc sense citrate cycle metabolites and/or ATP and may induce recurrent activation. We argue that the astrocytic calcium, GABA, and Glu signaling and altered sodium and chloride dynamics fundamentally shape metaplasticity by providing active regulatory roles in the synapse- and network-level flexibility of the NAc.
\end{abstract}

Keywords Nucleus accumbens macrosystem · Motivation-reward metaplasticity · Mixed GABAergic and Gluergic synapses . Perisynaptic astrocytic processes $\cdot$ Astrocytic endfeets $\cdot$ Succinate receptor

\section{Abbreviations}

5HT Serotonin (5-hydroxytryptamine)

Ach Acetylcholine

AKR7A2 Astrocytic succinic semialdehyde/aldo-keto reductase enzyme

AKR1B10 Succinic semialdehyde/aldo-keto enzyme

Julianna Kardos

kardos.julianna@ttk.mta.hu

1 Functional Pharmacology Research Group, Institute of Organic Chemistry, Research Centre for Natural Sciences, Hungarian Academy of Sciences, Magyar tudósok körútja 2, Budapest 1117, Hungary

2 Laboratory of Neuromorphology, Department of Anatomy, Histology and Embryology, Semmelweis University, Üllői út 26, Budapest 1086, Hungary

3 MTA-ELTE Laboratory of Molecular and Systems Neurobiology, Department of Physiology and Neurobiology, Eötvös Loránd University and the Hungarian Academy of Sciences, Pázmány Péter sétány 1C, Budapest 1117, Hungary

4 Human Brain Tissue Bank, Semmelweis University, Tűzoltó utca 58, Budapest H-1094, Hungary
Akr1b10 Succinic semialdehyde/aldo-keto

reductase gene

Aldh5A1 Mitochondrial succinic semialdehyde/aldo-keto reductase enzyme

Asp Aspartate

BBB Blood-brain barrier

CEC Citrate energy cycle

Cx43 Connexin 43

EAAT2 GLT-1, SLC1A2 - glial Na ${ }^{+}$ and $\mathrm{H}^{+}$ion-dependent excitatory amino acid transporter type 2 with $\left(1 \mathrm{Glu}: 3 \mathrm{Na}^{+}: 1 \mathrm{H}^{+}\right)_{\text {in }} /$ $\left(\mathrm{K}^{+}\right)_{\text {out }}$ stoichiometry

DA Dopamine (3,4-dihydroxyphenethylamine)

FC Frontal cortex

GABA $\gamma$-Aminobutyric acid

GAD Glutamic acid decarboxylase

GAT3 SLC6A11 - glial $\mathrm{Na}^{+}$and $\mathrm{Cl}^{-}$ion-dependent GABA transporter type 3 with (1GABA:2 $\left.\mathrm{Na}^{+}: 1 \mathrm{Cl}^{-}\right)$in stoichiometry

GFAP Glial fibrillary acidic protein

GHB $\quad \gamma$-Hydroxy butyric acid

GJ

Glu
Gap junction

Glutamate 


$\begin{array}{ll}\text { GluA2 } & \begin{array}{l}\text { AMPA receptor-alpha-amino-3-hydroxy-5- } \\ \text { methyl-4-isoxazole propionate receptor }\end{array} \\ \text { IOS } & \text { Intrinsic optical signal } \\ \text { Meth } & \text { Methamphetamine, N-methyl-amphetamine } \\ \text { mGluR5 } & \text { Group 1 metabotropic Glu receptor } \\ \text { NAc } & \text { Nucleus accumbens } \\ \text { NMDA } & N \text {-methyl- } D \text {-aspartate } \\ \text { Nqo2 } & \text { NAD(P)H dehydrogenase, quinone 2 gene } \\ \text { PAPs } & \text { Perisynaptic astrocytic processes } \\ \text { PV } & \text { Parvalbumin } \\ \text { Pvalb } & \text { Parvalbumin gene } \\ \text { Sgms2 } & \text { Sphingomyelin synthase gene } \\ \text { SOM } & \text { Somatostatin } \\ \text { SSA } & \text { Succinic semialdehyde } \\ \text { SSADH } & \text { Succinic semialdehyde dehydrogenase enzyme } \\ \text { Succinate } & \text { Sucn } \\ \text { Sucnr1 } & \text { Succinate receptor 1 gene } \\ \text { VTA } & \text { Ventral tegmental area }\end{array}$

\section{Organization of the Nucleus Accumbens}

Nucleus accumbens (NAc) is part of the ventral striatal division where circuit afferents and efferents both unite and segregate $[61,136]$ in distinctive neuronal ensembles [154]. Discernible NAc sub-territories of rodents, the "chameleonlike" shell and the core [67, 83, 186, 237, 241], are associated with the limbic and the motor systems, respectively [215]. In addition, core and shell sub-regions have many more functions, including incentive-cue responding and behavioral inhibition (see for example [6]). While rodent shell and core sub-regions and related neuronal circuit connections are clearly distinguishable [237], sub-region borders of human NAc are less apparent, displaying more diffuse, gradual changes in the topology of afferents and efferents [52, 107, 137]. We suggest that the characteristic differences between rodent and human NAc sub-territories are related to the diverse incentive-cue responding and behavioral inhibition of humans.

The major neuronal type in the nucleus accumbens is the medium spiny neuron (MSN), which comprise about $95 \%$ of the cells in the area. Neurochemical phenotypes of MSNs range from "quasi" inhibitory using the major inhibitory neurotransmitter $\gamma$-aminobutyric acid (GABA) to mixed inhibitory and excitatory (GABAergic and glutamatergic). Besides, ubiquitous distribution of terminals co-expressing vesicular glutamate (Glu) and GABA transporters in the striatum, hippocampus, thalamus, and cerebellar and cerebral cortices [45] suggests that the appearance of mixed Glu-GABA phenotypes may possibly be the rule rather than the exception (for a more thorough discussion on the possible significance of the mixed Glu-GABA MSN phenotype in the NAc, see the last paragraph of section "Basic Neurochemistry of Reward Quality and Prediction"). Accumbal MSNs exhibiting both GABA and Glu decarboxylase (GAD) immunoreactivity [5, 7, 227, 238] often co-express modulatory neuropeptides (substance $P$, dynorphin, enkephalin, and neurotensin) together with various dopamine (DA) receptor subtypes (DR1, DR2, and DR3). The DR1-DR2 receptor heteromer-expressing phenotype also takes up $\left[{ }^{3} \mathrm{H}\right]$ aspartate $\left(\left[{ }^{3} \mathrm{H}\right] \mathrm{Asp}\right)[156,227]$. The major DAergic input driving the different DA receptor types originates in the ventral tegmental area (VTA), while Gluergic inputs to the NAc arrive mostly from cortical areas. The latter innervations, however, also terminate on MSNs, raising the idea of "striatal synaptic triad." This represents a configuration of a Gluergic asymmetric spine head with a DAergic symmetric spine neck [50,62, 188], although asymmetrical morphology has also been considered [16, 100, 228, 239].

Interneurons $(<5 \%)$ in the NAc are mainly GABAergic, and to a lesser extent cholinergic, receiving serotonergic inputs $[192,218,238]$ in both the shell and core regions. The GABAergic interneurons exhibit nitric oxide synthase activity and somatostatin (SOM) and neuropeptide $\mathrm{Y}$ or parvalbumin (PV) expression. Gluergic input to the accumbal SOM expressing interneurons [169] may possibly evoke release of SOM specifically signaling to astrocytes [122]. The PVexpressing sub-population of interneurons has recently been noted as a major player in amphetamine sensitization and reward [226]. Also, we conjecture that the GABAergic PVexpressing NAc interneurons control the fast-firing MSNs, thereby shaping accumbal sensitization (for explanation and references cf. the last paragraph of the "Unique Glu-GABA Drives of the NAc" section). The GABAergic interneurons also receive both DAergic input from the VTA and glutamatergic innervation from cortical areas and in turn terminate on MSNs. Recently, Gluergic input from the VTA terminating on both interneurons and MSNs has also been established. This is the only Gluergic input to the NAc, which mediates aversion instead of reward [163]. Another small proportion of NAc neurons are tonically active cholinergic interneurons, which are the only source of acetylcholine (Ach) in the NAc [112]. These cells receive mostly Gluergic but also ascending serotonergic inputs and synapse onto MSNs through nicotinic (nAChR) and muscarinic acetylcholine (mAChR) receptors, which exert opposing effects on DA signaling. Whereas $\mathrm{nAChR}$ activation diminishes, $\mathrm{mAChR}$ activation increases motivation toward reward-predicting cues $([38,39]$ These cells were also identified as central players in the development of depression-like symptoms, because the disruption of cell surface expression of serotonin (5HT) receptors and/or other ion channels on cholinergic interneurons had antidepressant actions with therapeutic potential [225]. As to the molecular mechanisms, the expression and function of the hyperpolarization-activated cyclic nucleotide-gated channel 2 was suggested to be important as its overexpression in cholinergic interneurons was sufficient to rescue depressive 
phenotypes [31]. Recently, activation of serotonergic innervation from dorsal raphe nucleus to NAc was also found to be a prerequisite for normal social interaction in mice [222]. These findings qualify petite assemblies of accumbal interneurons as governing big networks associated with behavioral regimes. The operational blowup of interneuron activities shall require local and long-range neuro-glia coupling, to keep pace with the extreme energy demand of real-time dynamics of various molecular players and with the remodeling of synaptic morphology and neuronal circuitries.

\section{Basic Neurochemistry of Reward Quality and Prediction}

Reward sensitivity critically depends on the DA neurotransmitter system [19, 47, 203]. Incoming DAergic activity from the VTA in the NAc not only affects activity of the neuronal network but also affects astrocytic calcium signals, since they are dynamically modulated by D2R receptor activation [234]. In addition, DAergic stimuli induce the synthesis of modulatory neuropeptides, like dynorphin, enkephalin, neurokinin $\mathrm{A} / \mathrm{B}$, neurotensin, and substance $\mathrm{P}$ in astrocytes. The action mechanisms of neuropeptides in the NAc are particularly interesting within the framework of the future development of psychiatric drugs [59]. The DAergic VTA input in the NAc can regulate DA level by feedback mechanisms using collaterals to midbrain DA neuron areas. The incoming VTA signal affects neurons in the rostrodorsal and caudal parts of NAc differently (cf. "hotspots" and "coldspots" referenced below) based on separate co-expression patterns of various DA and opiate receptor subtypes. Endogenous ligands of opioid receptors, enkephalins, modulate locomotor activity by the facilitation of presynaptic DA release. D1R-positive MSNs express mu-opioid receptors predominantly, whereas D2R-positive neurons respond to delta and kappa ligands [7, 29]. Muopioid receptor agonists induce not only food intake but also food-reinforced operant behavior [185]. In contrast, accumbal DA receptor activation with amphetamine does not bear any feeding motivation component ([198], but see [194, 217]); nevertheless, it still produces self-stimulation behavior [23]. Opioids/cannabinoids or anandamide evoke their gustatory hedonic reaction by activating receptors distributed in a well-defined anatomical pattern, in the so-called "hotspots" in the NAc shell $[29,78,102,119,148]$. Together with muopioid receptors, delta- and kappa-opioid receptors are also clustered in the rostrodorsal region of NAc, enhancing gustatory hedonic reaction ("liking"). In contrast, the very same receptors mediating hedonic suppression map to the caudal part of NAc ("negative hedonic coldspot" $[29,30]$ ).

Accumbal instrumental learning [13, 27, 40, 64, 72, 91, $145,178,195,235]$ is a fundamental capability of an animal to weigh the utility of selected actions against the expected outcomes. This concept involves occurrence-dependent strengthening of response open to different interpretationsthat is, putting either "interaction" [171] or "reward" $[18,19$, $180]$ aspects in the limelight. In this respect, NAc is considered to be the main hub of the brain that-depending on the actual status of the ascending inputs from limbic structuresexercises sharp bivalent control over the operant behavioral output. Various types of in vivo NAc stimulation paradigms consistently yield opposite animal behavior: either reward/ appetitive or stress/aversive. The receptive fields of afferent fibers from prefrontal, entorhinal cortex, amygdala, or hippocampus show little spatial overlap, but individual NAc projecting neurons (GABAergic MSNs) demonstrate a high degree of synaptic convergence from the same input regions $[142,143]$. MSNs with mixed GABA-Glu phenotypes [156, 227] could well serve this principle. It is conceivable that at mixed GABA-Glu synapses, the ratio of Glu over GABA coreleased from these cells depends on the strengths and frequency of varied input stimulations [44, 141, 189]. Activitydependent shifting of the balance between GABA and glutamate release allows fine-tuning of transmission probability via changing prevalence of the inhibitory component (GABA). This way, accumbal MSNs with mixed GABA-Glu phenotypes predispose NAc to signal and drive positive or negative conducts.

\section{Unique Glu-GABA Drives of the NAC}

The medial prefrontal cortex relays taste information from the primary insular cortex, which constitutes the neuronal basis of food intake and energy homeostasis [20]. Local inhibition of ionotropic Glu receptors (or activation of $\mathrm{GABA}_{\mathrm{A}}$ receptors) in the shell region of NAc evokes strong feeding response (or positive place preference in other experimental paradigms) by inhibiting MSNs that disinhibit upstream targets like the lateral hypothalamus, ventral pallidum (VP), or VTA [198]. Early studies indicated that the major excitatory input from the medial prefrontal cortex to the anterior pole of NAc (cortico-accumbal pathway) uses Glu or Asp as neurotransmitter [36, 37]. Subsequently, it was demonstrated that feeding induces ambient (Glu) increase in the lateral hypothalamus and decrease in the accumbal (Glu) that was detected by microdialysis probes inserted into the NAc [164]. NAc receives Gluergic inputs from the ventral hippocampus [12, 21, 95] suggesting that depression and drug/ethanol reward behaviors are furthered via the strengthening of these synapses. Recently, a chemogenetic approach has been applied to distinguish the contribution of the activation of VTA-GABA neurons from other mesoaccumbal nerve terminals to incentive salience. The results indicate that VTA-GABA neurons, but not GABA projections, disrupt incentive salience processes [221]. 
Several lines of evidence support the crucial aspects of NAc in drug reward modulation [10, 60, 103, 157, 243]. Upon chronic exposure to cocaine, the accumbal alpha-amino-3-hydroxy-5-methyl-4-isoxazole propionate receptor (GluA2/ AMPA receptor) is upregulated [92], and NMDA receptordependent long-term depression in MSNs in the core region of NAc is suppressed [88]. It is to note that extinction and reconsolidation of cocaine seeking behavior monitored by mass spectrometry-based phosphoproteomics disclosed Gluergic basolateral amygdala inputs to NAc as being crucial for cocaine cue exposure [209]. The drug-seeking behavior could be associated with synaptic changes, such as dendritic spine head diameter and AMPA/NMDA receptor ratio [197]. Extracellular Glu in the NAc is modulated by group 2 metabotropic Glu receptors [233]. Group 2 and 3 metabotropic Glu receptors operate at prefrontal cortical axon terminals and modulate DAergic transmission at the same synapse [121]. Although Glu or GABA activation can evoke similar positive/negative motivational patterns, the effect of GABA holds a hedonic component as well. The major source of GABAergic innervation in the NAc arises from local aspiny interneurons [7, 15]. Apparently, these neurons provide the feed-forward inhibition of neighboring MSNs during excitatory stimulation from descending cortical and hippocampal structures. Presynaptic GluK1/2 heterodimer kainate receptors at cortical afferents play a major role in this inhibition of MSN activity, because GluK1/2 receptor activation decreases glutamatergic but increases GABAergic synaptic transmission in the NAc $[28,39]$.

The "all or none" type of control of fast-spiking MSNs by the GABAergic PV-containing accumbal interneuron ensemble implies unique functional significance [101, 104, 238] such as sensitization [208]. The bivalent nature of NAc output $[167,168,170]$ to different basal ganglia and mesencephalic structures is discernible already at the electrophysiological characteristics of the MSNs that also show bistability [105]. MSNs display spontaneous transition of membrane potential between a more hyperpolarized, resting "down state" and a more depolarized, active "up state" - only when barrages of action potentials can be discharged [142]. Similarly, the influence of hippocampal interneurons on the output of cooperating principal cells would serve to induce synaptic enhancement in target structures during behavioral inactivity, consumer behaviors, and slow-wave sleep [25]. Based on findings showing that cortical astrocytes play an indispensable role in cortical state switching [162] and even in the generation of genuine, physiological slow-wave activity in vivo [200], it is suggested that astrocytes may trigger the same coordination of neuronal "up" and "down" state oscillations of accumbal MSNs. Consequently, the heavily gap junctioncoupled, easily synchronizable astrocyte network may significantly contribute to the coordinated activation of the NAc circuitry, eventually establishing synaptic reinforcement (see also "Rising Astrocyte Waves: New Layers of Accumbal Neuro-Glia Coupling" section).

\section{Modulation of Inhibitory Signaling by Converging Metabolic and Reward Pathways}

Emerging themes, like cellular stress, hypoxia, and inflammation, are examples of functional association between signaling molecules and citrate energy cycle (CEC) metabolites [211], primarily succinate (Sucn) $[34,124,158,202]$. Fumarate accumulation associated with glutaminolysis also presents a hallmark of cellular defense mechanism [9]. Mutations of the mitochondrial succinic semialdehyde gene (aldo-keto reductase Aldh5A1) cause succinic semialdehyde dehydrogenase (SSADH) deficiency [120, 219]. In this case, the conversion of SSA to Sucn by SSADH is diminished, while the accumulation of $\gamma$-hydroxybutyric acid (GHB) from GABA is maintained. Different responses to methadone maintenance treatment have been explained by a deviation of GABA catabolism from the CEC due to altered Aldh5A1 expression in opioid-dependent patients [48].

Genes repressed in the NAc and the frontal cortex (FC) of cocaine-, morphine-, and ethanol-vulnerable Lewis rats [73] help to uncover associated signaling and metabolism, underlying the manifestation of addiction, an important behavioral extremity. Higuera-Matas and co-workers [73] highlighted some genes as being associated with (i) changes in the striatum of cocaine-sensitized rats (parvalbumin/Pvalb) [208]; (ii) drug addiction (sphingomyelin synthase, Sgms2) [177]; and (iii) methamphetamine (Meth)-induced psychosis (NAD(P)H dehydrogenase, Nqo2) [79, 146]. Importantly, genes for Sucn receptor 1 (Sucnr1) and aldo-keto reductase AKR1B10 (Akrlb10) involved in Sucn biosynthesis were also repressed in both the FC and the NAc of Lewis rats [73]. Indeed, the significant role for PV-positive accumbal interneurons in drug-related learning is substantiated by recent data demonstrating PV-positive GABAergic interneurons as a prerequisite for psychostimulant (amphetamine)-induced behavioral adaptation [[223]; discussed by [226]].

Expression data alone may not be sufficient to explain changes in network stability or infer causality in reward/ addiction process. Yet, these considerations and findings may allow speculations on a possible functional link between the danger signal Sucn [202] and reward/addiction processes. Both the coincidence and synergy of ATP- and Sucn/GHB-responsive astrocytic calcium transients together with the presence of high-affinity Sucn/GHB recognizing sites in the NAc [128-133] strongly imply the involvement of a Sucn-responsive astrocytic target. This positive feedback mechanism supports the nucleation-type model [118] of the astrocyte network activation dynamics 
in the NAc. The "Sucn signal" could directly target some GPR91-type G protein-coupled Sucn receptors [8, 65, $131,166,175,179,210]$. The expression of P2Y1 receptors in accumbal astrocytes [49] and $\mathrm{P} 2 \mathrm{Y} 1$ receptor antagonist sensitivity of the Sucn- and ATP-responsive calcium transients sensibly predicts interference of Sucn and P2Y1 receptor-mediated calcium mobilization [131]. Nevertheless, the potential validation of brain-type Sucn receptors may reveal distinguishable binding crevices (Table 1) [242]. Sucn binding could also be linked to the mitochondrial Sucn dehydrogenase for which Sucn is the substrate $[84,199,201]$. Also, Sucn may function through some mitochondrial dicarboxylate carriers (Table 1) $[80,139,150]$. It is worth mentioning that neuronal activity-independent calcium bursts have been described in the Bergmann glia of behaving animals and were found to be purinergic [140]. It is conceivable that coincidence of both Sucn- and ATP-responsive calcium bursts at the blood-brain barrier (BBB) [131] may in turn reflect neuron-independent activation of Sucn-deficient astrocytes by the micromolar Sucn supply from blood [65].

\section{Rising Astrocyte Waves: New Layers of Accumbal Neuro-Glia Coupling}

Maintenance of the significant energy demand of balanced Glu-GABA signaling depends on proper neuroglia metabolic coupling in various physiological and disease conditions $[14,68,69,89,129,131,149,174,200$, $213,231]$; for reviews see $[4,70,86,87,96,97,110,184$, 216]. This dependency is highlighted by the observation that complexes between the astrocytic Glu transporter EAAT2 and the $\alpha 2$ isoform of $\mathrm{Na}^{+} / \mathrm{K}^{+}$-ATPase are concentrated in the perisynaptic astrocytic processes (PAPs), which also indicates a unique role for Glu homeostasis [123]. Thus, we coin the term tripartite metaplasticity that signifies not only the prior record of the synaptic activity of the neuronal (see for example [207] and reference herein) but also that of the astrocytic moduls within the synapse, whereby a new level of "plasticity of synaptic plasticity" (metaplasticity $[1,2]$ ) is attained. Accordingly, we suggest astrocytic activation [3] and tripartite metaplasticity [2, 33, 56, 110], 2011, 2013; [125, 193] as new substrates of behavioral motivation to action driven by the NAc.

Reactive astrogliosis associated with elevated SSA reductase AKR7A2 [159] may serve as a mechanistic clue for the early appearance of both astroglyopathy in cortico-basal degeneration [114] and modulation of reward/addiction behavior [24]. For example, chronic drug abuse is characterized by astrocytic hypertrophy, astrocytopathy, and astrogliosis [53,
94]. These morphological and pathological changes trigger Glu uptake via EAAT2. The ensuing alteration of Glu and GABA homeostasis and pertinent metabolism $[11,181]$ cause altered glial fibrillary acidic protein (GFAP) [54, 183] and EAAT2 expressions [187].

Regarding the astrocytic control over GABAergic actions, tonic inhibition of the extrasynaptic $\delta$-containing $\mathrm{GABA}_{\mathrm{A}}$ receptors can be induced by GABA release through the astrocytic GABA transporter (GAT3) due to EAAT2 activation. Moreover, the neuronal activitydependent exchange of GABA for Glu also influences the power of in vivo gamma oscillations as monitored in the rat hippocampus [69]. This mechanism is adjusted by astrocytic GABA production from polyamines by monoamine oxidize B $[69,236]$. Several lines of pharmacological evidence suggest that turning excitation into inhibition by astrocytes may also be relevant to NAc. Reportedly, chronic monoamine oxidase B inhibitor treatment diminished cocaine reward in mice [74]. Also, extrasynaptic $\delta$-containing $\mathrm{GABA}_{\mathrm{A}}$ receptors in the NAc dorsomedial shell played a role in alcohol intake [138]. It is proposed therefore that the astrocytic Glu-GABA exchange mechanism revealed in the hippocampal formation and the striatum $[68,69,231]$; for reviews see $[86,87,93$, 96, 97, 216] may also modulate NAc functions by adapting tonic inhibition. It is tempting to speculate about the likely correlation of connexin $43(\mathrm{Cx} 43)$-positive astrocytes in the NAc [129] with the expression of astrocytic GAT3 and EAAT2 in light of the Glu-GABA exchange mechanisms. Also, the induction of EAAT2 expression and trafficking or the motility of the PAPs ([87] and references cited therein) raises the possibility of excitationinduced co-localization of EAAT2 with GAT3 [71, 110, $135,144,152]$. It is noteworthy that the "gliocentric" (references cited above, and [172]) and "neurocentric" [147] views of inhibitory plasticity corroborate in terms of the chloride gradient shift across the neuronal membrane.

One of the most remarkable manifestations of chloride signaling in the bidirectional communication between neurons and astrocytes in the brain [229] is the spatiotemporal intrinsic optical signal (IOS). The IOS, generated by action potentials and robustly enhanced by disinhibition via $\mathrm{GABA}_{\mathrm{A}}$ receptor blockade, progresses by activation of Glu receptors and astrocytic Glu transporters [149]. Alteration of tonic inhibition due to EAAT2-mediated Glu-GABA exchange occurs at the astrocytic leaflets preferentially contacting synapses [51] of synaptic islands [63]. These findings also point to the significance of EAAT2 activation-induced astrocytic GAT3 reversal not only in terms of extrasynaptic $\mathrm{GABA}_{\mathrm{A}}$ receptor activation but also as a mechanism to sensitively modulate chloride gradient and neuronal excitability in this way 
Table 1 Comparison of putative binding sites of potential Sucn targets in the brain

\begin{tabular}{|c|c|c|}
\hline Potential Sucn targets & Putative binding site* & References \\
\hline $\begin{array}{l}\text { P2Y1 } \\
\text { PDB code: } 4 \text { XNW } \\
\text { in complex with }(R)-M R S 2500 \text { antagonist** }\end{array}$ & $\begin{array}{l}\text { Arg287, Leu44, Asn283, } \\
\text { Cys42 }\end{array}$ & $\begin{array}{l}\text { Zhang et al., } \\
2015\end{array}$ \\
\hline $\begin{array}{l}\text { Sucn receptor model } \\
\text { based on the structure of bovine rhodopsin }\end{array}$ & $\begin{array}{l}\text { Arg99, His103, Arg252, } \\
\text { Arg281 }\end{array}$ & He et.al., 2004 \\
\hline $\begin{array}{l}\text { Sucn receptor model*** } \\
\text { based on the structure of bovine rhodopsin }\end{array}$ & $\begin{array}{l}\text { Arg99, His103, Tyr107, } \\
\text { Asn173, His249, } \\
\text { Met251, Arg252 }\end{array}$ & $\begin{array}{l}\text { Molnár et al., } \\
2011 b\end{array}$ \\
\hline $\begin{array}{l}\text { Sucn receptor model } \\
\text { based on the structure of } \mathrm{P} 2 \mathrm{Y} 1\end{array}$ & $\begin{array}{l}\text { Arg255, Arg281, } \\
\text { Asp174 }\end{array}$ & $\begin{array}{l}\text { Trauelsen et al., } \\
2017\end{array}$ \\
\hline $\begin{array}{l}\text { Sucn dehydrogenase } \\
\text { PDB code: } 1 Z P 0, \text { porcine numbering }\end{array}$ & $\begin{array}{l}\text { Gly63, His254, Thr266, } \\
\text { Glu267, Arg298, } \\
\text { His365, Arg409, Ala412 }\end{array}$ & $\begin{array}{l}\text { Sun et al., 2005; } \\
\text { reviewed in } \\
\text { Iverson, } 2013\end{array}$ \\
\hline $\begin{array}{l}\text { Mitochondrial dicarboxylate carrier } \\
\text { (DIC; SLC25A10) } \\
\text { The model of DmDIC1p based on a } \\
\text { mitochondrial ADP/ATP carrier. }\end{array}$ & $\begin{array}{l}\text { Arg69, Tyr73, Arg77, } \\
\text { Arg164, Gly165, Arg257 }\end{array}$ & $\begin{array}{l}\text { Palmieri et al., } \\
1996 \\
\text { lacopetta et al., } \\
2011\end{array}$ \\
\hline $\begin{array}{l}\text { VcINDY } \\
\text { PDB code: } 5 U L 7 \\
\text { Divalent anion/ } \mathrm{Na}^{+} \text {symporter from vibrio } \\
\text { cholarae, homologous to mammalian } \\
\text { sodium-dicarboxylate cotransporter } 3 \\
\text { (NADC3) }\end{array}$ & $\begin{array}{l}\text { Asn151, Thr152, } \\
\text { Ser200, Ser377, } \\
\text { Asn378, Thr379, Thr421 }\end{array}$ & Nie et al., 2017. \\
\hline
\end{tabular}

*Basic, acidic, polar, or neutral characters of amino acid residues are indicated with blue, red, yellow, or black colors, respectively

**P2Y1 receptor couples via Gq proteins and stimulates phospholipase C followed by increases in IP3 and mobilization of calcium from intracellular stores [220]

***Amino acids surrounding Sucn within $4 \AA$

[165]. From a teleological point of view, MSNs with mixed glutamatergic-GABAergic phenotypes fit the mechanistic clue.

Glu receptor pharmacology may also give an insight into the role of astrocyte activation mechanisms. For example, activation of the group 1 metabotropic Glu receptor (mGluR5) expressed by NAc-resident astrocytes results in a prolonged astrocyte-dependent gliotransmission and stimulation of NMDA receptor-dependent slow inward current in MSNs $[41,46]$. In addition to its vital role for promoting resilience to chronic stress [191], accumbal mGluR5s do impact drug-related behaviors. Furthermore, the inhibitory control of astrocyte activation pathways by antagonists of mGluR5 can interfere with cocaine-seeking behavior $[111,204]$. Cocaine withdrawal impairs mGluR5dependent long-term depression in the shell neurons of NAc [77]. It is to note that mGluR 1 and mGluR5 modulate distinct excitatory inputs to the NAc shell [212]. The involvement of astrocytic metabotropic Glu receptor is therefore consistent with the positive feedback cell signaling nucleation model of astrocyte dynamics [118].

Further, we can speculate about the significance of the involvement of other $G$ protein-coupled receptors, such as accumbal P2Y1 or Sucn1. Indeed, we can observe slow, recurrent calcium dynamics at a rate of about 3-4 every 10 min evoked by ATP or energy metabolites [129, 131]. Such a recurrent and pacemaker activity of astrocytes has already been described $[153,160,161]$ and been related to gliotransmitter (Glu/Asp) releasedependent sustained neuronal activity. By itself, astrocyte activation-related intermittent calcium and sodium transients [[86]; Kirischuk et al., 2017] are consistent with the ideas of (i) flexible tuning of the tripartite synapses, 
(ii) linked domains of astrocytic syncytium via neuro-glia coupling, and (iii) negative feedback through the astrocytic Glu-GABA exchange signaling. According to this hypothesis (Fig. 1), astrocytes are ideally positioned to control the plasticity of mixed Gluergic/GABAergic synapses. Depending on local activation and propagating $\mathrm{Ca}^{2+}$ waves through the astrocytic syncytium due to high-frequency stimulation, cocaine exposure, lactation, or other stimuli, NAc astrocytes can adjust their morphology $[155,205,206]$ resulting in different coverages of the synapse. Since Glu uptake and spillover is crucially dependent on astrocytic coverage, the tightness of astrocyte wrapping of the synapse can finely tune the balance between inhibitory and excitatory outcomes (Fig. 1). Indeed, in a rodent model of ethanol selfadministration using astrocyte-specific designer receptors to reduce ethanol self-administration, Glu-based bidirectional neuron-astrocyte communication was found in the NAc core, claimed to be important for circuitry guiding motivated behavior [24]. Evidence on interglial gap junction (GJ) channel coupling as a causative agent was also provided [24]. Similarly, activation of an astrocyte-

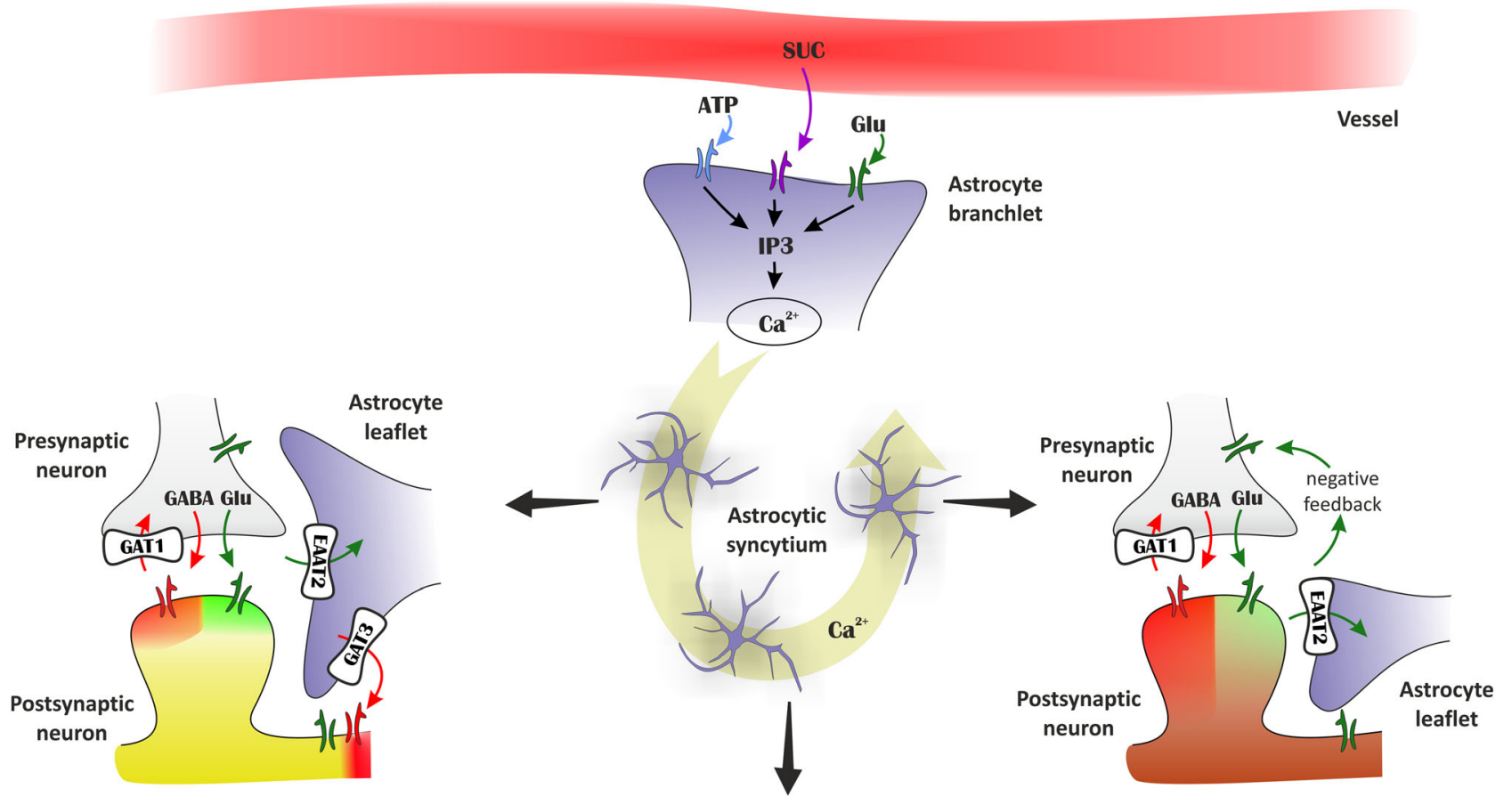

\section{Tightly wrapped synapse}

excitation and

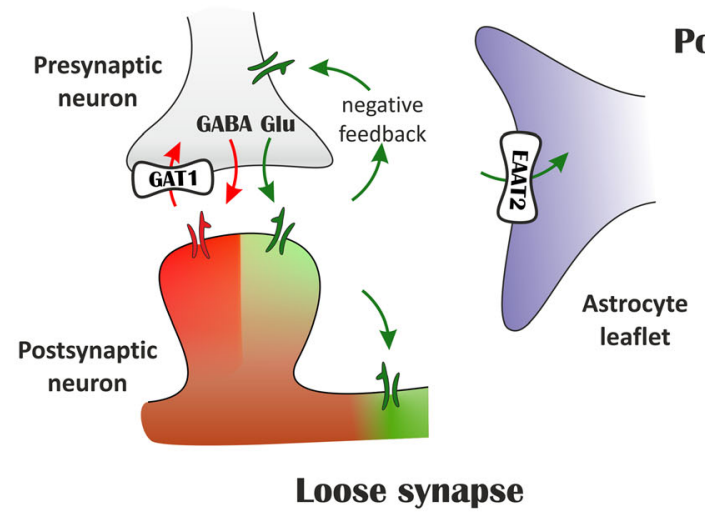

Local inhibition

Volume excitation
Fig. 1 Astrocytes may dynamically control plasticity of mixed inhibitory and excitatory synapses. In the tightly wrapped synapse (left), Glu transporters facing the synapse can quickly take up released Glu, thereby preventing the activation of extrasynaptic Glu receptors. The simultaneous activation of synaptic GABA and Glu receptors results in balanced excitation and inhibition. During intense excitation, EAAT2 activity may also induce GABA release by reverse transport, thereby generating tonic inhibition $[68,69]$. When astrocytic leaflets are withdrawn from the synapse (bottom), reduced Glu uptake leads to activation of presynaptic mGluRs inhibiting further Glu release and of extrasynaptic Glu receptors increasing tonic excitation. Asymmetric astrocytic coverage of axonal boutons and dendritic spines (right) [51] favors reduced Glu release by activating presynaptic mGluRs, resulting in a dominantly inhibitory response following GABA/Glu co-release 
specific designer Gq receptor selectively initiates Glu release and inhibits cue-induced cocaine seeking [182]. Increased neuronal activity and long-term potentiation induce a broader coverage of synapses by PAPs. Strong, prolonged activation, like lactation, results in a decrease in PAP coverage (Fig. 1) [17].

\section{The Macrosystem NAc-from Motivation to Action}

Macrosystem (Fig. 2) metaplasticity may possibly be better characterized as an arousal-driven specific acquisition/ approach and reinforcement of accumbal circuitries, rather than as a general adaptive NAc response $[22,23,57,61,82$, $127,136,154,176,230,238,240]$. The NAc is embedded into the larger cortico-basal ganglia-thalamo-cortical loop and is considered to be a main integration center of the basal ganglia. Being part of the ventral striatum, the major connection to the NAc is from afferents of pyramidal cells populating the layers II-VI of parts of the prefrontal cortex, with an indirect massive contribution from the anterior cingulate cortex. These afferents supply the higher order perceptive, homeostatic, anticipative, and emotional state information to the NAc and represent a major route of sensory information toward the NAc together with some direct thalamic inputs. In addition,

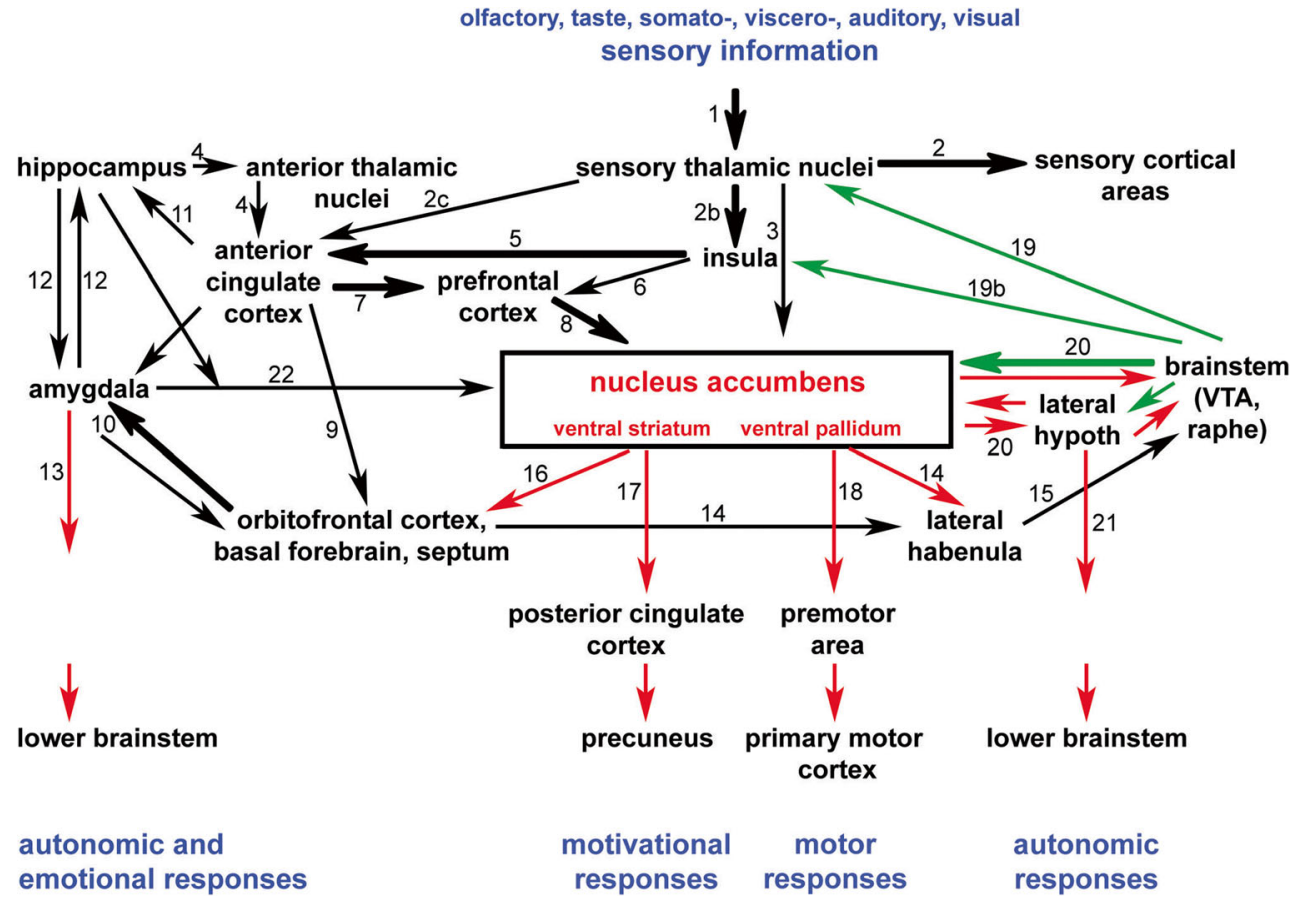

Fig. 2 Afferent and efferent connections of the accumbens/ventral striatum. The scheme represents the neuronal pathway interconnectivity converging onto and originating from the nucleus accumbens (NAc)/ ventral striatum/pallidum. Different modalities of sensory information reach the NAc through the sensory thalamic nuclei directly and indirectly, too. These glutamatergic inputs (black arrows) are combined in the NAc with monoaminergic (dopaminergic and serotonergic) inputs (green) from the ventral tegmental area (VTA) and the raphe nuclei, respectively. The projections from the NAc are inhibitory (red arrows). Efferent projections to cerebral brain regions initiate motivational and motor responses, while indirect output to the lateral hypothalamus and the amygdala initiates autonomic and emotional responses. Thick arrows represent particularly massive projections. The white matter tracts where the different pathways are located are indicated by numbers as follows: (1) ascending somato- and viscerosensory pathways to the thalamus; (2) thalamocortical radiation; (2b) sensory inputs to the posterior insular cortex; (2c) sensory inputs to the anterior cingulate cortex; (3) thalamostriatal and pallidal projections; (4) hippocampal-anterior thalamicanterior cingulate cortex connections through the "Papez circle"; (5) anterior insular projections to the anterior cingulate cortex (the two hubs of the salience network); (6) direct anterior insular projections to the prefrontal cortex (to the ventrolateral and dorsolateral prefrontal cortex); (7) bilateral anterior cingular-prefrontal cortical fiber connections; (8) prefrontal neuronal feedback to the nucleus accumbens; (9) bilateral anterior cingular-orbitofrontal cortical fiber connections; (10) bilateral connections between the orbitofrontal cortex and the amygdala (uncinate fascicle); (11) anterior cingulate projections to the hippocampus through the parahippocampal cortex; (12) amygdala connections with the hippocampus (via peri- and entorhinal cortex); (13) descending amygdala projections to the lower brainstem (partly through the stria terminalis); (14) stria medullaris thalami; (15) fasciculus retroflexus; (16) nucleus accumbens, ventral striatal/pallidal projections to the orbitofrontal cortex, basal forebrain, and septum; (17) fibers from the nucleus accumbens/ventral striatal and pallidal neurons in the frontoparietal neuronal connections ("dorsal default mode network"); (18) nucleus accumbens, ventral striatal/pallidal projections to the premotor and motor cortical areas; (19) ascending brainstem dopaminergic (from the ventral tegmental area) and serotinergic fibers (from the midline midbrain raphe nuclei) to the thalamus (one portion of the ascending reticular activating system); (19b) ascending brainstem dopaminergic and serotinergic fibers to the insula; (20) medial forebrain bundle; (21) descending fibers from the lateral hypothalamus to the lower brainstem; (22) ventral amygdalofugal pathway 
a powerful glutamatergic pathway from the basolateral amygdala innervates both the shell and core of the NAc that are implicated in motivational salience, affective behavior, and emotion. The ventral pallidum is the primary output area of NAc. Efferent projections from the NAc are ultimately cortical areas, such as the precuneus via the posterior cingulate cortex and the motor cortex to provide incentives for the execution of motor responses. The NAc can also affect autonomic and emotional responses via the amygdala and the lateral hypothalamus. Importantly, the mesolimbic dopamine (DA) pathway partially via the lateral hypothalamus is responsible for positive reinforcement by reward that can be traced to NAc and ventral pallidum. The more medial areas of the hypothalamus send aversive signals to the same receivers; thus, high spatial and functional selectivity must exist among the adjacent mesolimbic DA fibers. The NAc also receives potent serotonergic inputs that bind to several types of 5HT receptors (5HT1-4). Serotonin potently interferes with the mesolimbic DA pathway and overrides the inhibitory action of DA in selected neurons in the shell region. The NAc can also affect these brainstem centers directly and also indirectly via the orbitofrontal cortex, the basal ganglia, the septum, and the lateral habenula. Several lines of evidence can be found in the realm of expert's practice and relevant scientific literature. For example, the NAc/ventral striatum of the accumbal macrosystem drives and reinforces reward-associated feeding and sexual or somatic and visceral (loco)motor actions, including repetitive behavior $[20,32,35,42,43,55,66,73$, $90,98,99,106,117,173,214,232,244]$. Motivations, shaping the emotional [76] or cognitive addiction behavior [81, 83, 190, 196] via activating the NAc-hippocampus and hypothalamus-NAc circuits, respectively, have the potential of alternative execution as well. Evidently, the various higher order brain functions, like the motivational, adaptive, and goal-directed behaviors impinging upon and originating from the NAc, underlie why this basal ganglia nucleus function is prone to be hijacked by illicit substances and neurotransmitter mimetics in an abusive manner.

\section{Conclusions}

Future research is needed to unravel the context in which astrocyte activation may specifically stimulate neuronal ensembles of the accumbal macrosystem to function in different directions $[26,58,115,116]$. Although accumbal circuit connections and silent synapses grant a high degree of both specificity and neuronal metaplasticity potential [108, 109, 151], there seems to remain room for including additional concepts, such as astrocytic "randomness" arising from activitydependent rearrangements of energy metabolism, morphology, GJ-coupled domains, distal astrocytic processes, or synaptic leaflets during later stages of reinforcement. These studies may also imply that astrocytes do not only act in response to accumbal neuronal ensembles but also combine metabolic energy, they modulate signaling by supporting different (positive and negative) outcomes. Beyond the potential significance of astrocytic interleukin-6 [113] and leptin [134, 224] signaling, or ionotropic/metabotropic Glu receptor subunitspecific synaptic potentiation $[3,75,108-110,126]$, the enhanced allocation of reward-associated gamma oscillations [85] may open up novel therapeutic opportunities.

Below the thunders of the upper deep,

Far far beneath in the abysmal sea,

His ancient, dreamless, uninvaded slee

The Kraken sleepeth:

Tennyson, Alfred Lord: The Kraken

http://www.poemhunter.com/poem/the-kraken-2/

Author's Contribution JK participated in the design, coordinated the study, and drafted the manuscript. ÁD evaluated immunohistochemical data and carried out documentation materials. ZsSz helped to draft the manuscript; ÁS considered relevant bioinformatics; GL and MP evaluated anatomical studies. LH participated in the design, helped to draft the manuscript, and carried out documentation materials. All authors read and approved the final manuscript.

Funding Open access funding provided by MTA Research Centre for Natural Sciences (MTA TTK). This work was supported by grants KMR_12-1-2012-0112 TRANSRAT, VEKOP-2.1.1-15-2016-00156 and OTKA K124558.

\section{Compliance with Ethical Standards}

Ethics Approval and Consent to Participate Not relevant.

Consent for Publication Not relevant.

Availability of Supporting Data Not relevant.

Competing Interests The authors declare that they have no competing interests.

Open Access This article is distributed under the terms of the Creative Commons Attribution 4.0 International License (http:// creativecommons.org/licenses/by/4.0/), which permits unrestricted use, distribution, and reproduction in any medium, provided you give appropriate credit to the original author(s) and the source, provide a link to the Creative Commons license, and indicate if changes were made.

\section{References}

1. Abraham WC, Bear MF (1996) Metaplasticity: the plasticity of synaptic plasticity. Trends Neurosci 19:126-130

2. Abraham WC (2008) Metaplasticity: tuning synapses and networks for plasticity. Nat Rev Neurosci 9:387-399

3. Adamsky A, Kol A, Kreisel T, Doron A, Ozeri-Engelhard N, Melcer T, Rafaeli R, Horn H et al (2018) Astrocytic activation 
generates de novo neuronal potentiation and memory enhancement. Cell 174:59-71

4. Allen NJ, Eroglu C (2017) Cell biology of astrocyte-synapse interactions. Neuron 96:697-708

5. Al-Muhtasib N, Forcelli PA, Vicini S (2018) Differential electrophysiological properties of D1 and D2 spiny projection neurons in the mouse nucleus accumbens core. Physiol Rep 6:e13784

6. Ambroggi F, Ghazizadeh A, Nicola SM, Fields HL (2011) Roles of nucleus accumbens core and shell in incentive-cue responding and behavioral inhibition. J Neurosci 31:6820-6830

7. Angulo JA, McEwen BS (1994) Molecular aspects of neuropeptide regulation and function in the corpus striatum and nucleus accumbens. Brain Res Rev 19:1-28

8. Ariza AC, Meinardus P, Deen T, Robben JH (2012) The succinate receptor as a novel therapeutic target for oxidative and metabolic stress-related conditions. Front Endocrin 3:article22

9. Arts RJV, Novakovic B, ter Horst R, Carvalho A, Bekkering S, Lachmandas E, Rodrigues F, Silvestre R et al (2016) Glutaminolysis and fumarate accumulation integrate immunometabolic and epigenetic programs in trained immunity. Cell Metab 24:807-819

10. Augur IF, Wyckoff AR, Aston-Jones G, Kalivas PW, Peters J (2016) Chemogenetic activation of an extinction neural circuit reduces cue-induced reinstatement of cocaine seeking. J Neurosci 36:10174-10180

11. Ayers-Ringler JR, Jia Y-F, Qiu Y-Y, Choi D-S (2016) Role of astrocytic glutamate transporter in alcohol use disorder. World $\mathrm{J}$ Psychiatry 6:31-42

12. Bagot RC, Parise EM, Peña CJ, Zhang HX, Maze I, Chaudhury D, Persaud B, Cachope R et al (2015) Ventral hippocampal afferents to the nucleus accumbens regulate susceptibility to depression. Nat Commun 6:7062 Erratum in: Nat Commun 2015, 6:7626 by Cheer JF.

13. Baldwin AE, Sadeghian K, Holahan MR, Kelley AE (2002) Appetitive instrumental learning is impaired by inhibition of cAMP-dependent protein kinase within the nucleus accumbens. Neurobiol Learning Memory 77:44-62

14. Bélanger M, Allaman I, Magistretti PJ (2011) Brain energy metabolism: focus on astrocyte-neuron metabolic cooperation. Cell Metab 14:724-738

15. Bennett BD, Bolam JP (1994) Synaptic input and output of parvalbumin-immunoreactive neurons in the neostriatum of the rat. Neurosci 62:707-719

16. Bennett BD, Wilson CJ (2000) Synaptology and physiology of neostriatal neurones. In: Miller R, Wickens JR (eds) Brain dynamics and the striatal complex. CRC Press Harwood, Amsterdam, pp. 111-140

17. Bernardinelli Y, Muller D, Nikonenko I (2014) Astrocyte-synapse structural plasticity. Neural Plast 2014:232105

18. Berridge KC, Robinson TE (2003) Parsing reward. Trend Neurosci 26:507-513

19. Berridge KC, Robinson TE (1998) What is the role of dopamine in reward: hedonic impact, reward learning, or incentive salience? Brain Res Rev 28:309-369

20. Berthoud HR (2002) Multiple neural systems controlling food intake and body weight. Neurosci Biobehav Rev 26:393-428

21. Britt JP, Benaliouad F, McDevitt RA, Stuber GD, Wise RA, Bonci A (2012) Synaptic and behavioral profile of multiple glutamatergic inputs to the nucleus accumbens. Neuron 76:790-803

22. Brodal HP, Osnes B, Specht K (2017) Listening to rhythmic music reduces connectivity within the basal ganglia and the reward system. Front Neurosci 11:article 153

23. Broekkamp CL, Pijnenburg AJ, Cools AR, Van Rossum JM (1975) The effect of microinjections of amphetamine into the neostriatum and the nucleus accumbens on self-stimulation behaviour. Psychopharmacologia 42:179-183
24. Bull C, Freitas KCC, Zou S, Poland RS, Syed WA, Urban DJ, Minter SC, Shelton KL et al (2014) Rat nucleus accumbens core astrocytes modulate reward and the motivation to self-administer ethanol after abstinence. Neuropsychopharmacology 39:28352845

25. Buzsáki G, Horváth Z, Urioste R, Hetke J, Wise K (1992) Highfrequency network oscillation in the hippocampus. Science 256(5059):1025-1027

26. Cadet JL, Bisagno V (2014) Glial-neuronal ensembles: partners in drug addiction-associated synaptic plasticity. Front Pharmacol 5: Article204

27. Cardinal RN, Cheung THC (2005) Nucleus accumbens core lesions retard instrumental learning and performance with delayed reinforcement in the rat. BMC Neurosci 6:9

28. Casassus G, Mulle C (2002) Functional characterization of kainate receptors in the mouse nucleus accumbens. Neuropharmacol 42: 603-611

29. Castro DC, Berridge KC (2014) Opioid hedonic hotspot in nucleus accumbens shell: mu, delta and kappa maps for enhancement of sweetness "liking" and "wanting". J Neurosci 34:4239-4250

30. Castro DC, Cole SL, Berridge KC (2015) Lateral hypothalamus, nucleus accumbens, and ventral pallidum roles in eating and hunger: interactions between homeostatic and reward circuitry. Front Syst Neurosci 9:90

31. Cheng J, Umschweif G, Leung J, Sagi Y, Greengard P (2019) HCN2 channels in cholinergic interneurons of nucleus accumbens shell regulate depressive behaviors. Neuron 101:662-672.e5

32. Cheng J, Wang J, Ma X, Ullah R, Shen Y, Zhou Y-D (2018) Anterior paraventricular thalamus to nucleus accumbens projection is involved in feeding behavior in a novel environment. Front Mol Neurosci 11:article 202

33. Choi M, Ahn S, Yang E-J, Kim H, Chong YH, Kim H-S (2016) Hippocampus-based contextual memory alters the morphological characteristics of astrocytes in the dentate gyrus. Molecular Brain 9:72

34. Chouchani ET, Pell VR, Gaude E, Aksentijević D, Sundier SY, Robb EL, Logan A, Nadtochiy SM et al (2014) Ischaemic accumulation of succinate controls reperfusion injury through mitochondrial ROS. Nature 515(7527):431-435

35. Choudhary AG, Somalwar AR, Sagarkar S, Rale A, Sakharkar A, Subhedar NK, Kokare DM (2018) CART neurons in the lateral hypothalamus communicate with the nucleus accumbens shell via glutamatergic neurons in paraventricular thalamic nucleus to modulate reward behaviour. Brain Struct Funct 223:1313-1328

36. Christie MJ, James LB, Beart PM (1985) An excitant amino acid projection from the medial prefrontal cortex to the anterior part of nucleus accumbens in the rat. J Neurochem 45:477-482

37. Christie MJ, Summers RJ, Stephenson JA, Cook CJ, Beart PM (1987) Excitatory amino acid projections to the nucleus accumbens septi in the rat: a retrograde transport study utilizing $\mathrm{D}\left[{ }^{3} \mathrm{H}\right]$ aspartate and $\left[{ }^{3} \mathrm{H}\right] \mathrm{GABA}$. Neuroscience 22:425-439

38. Collins AL, Aitken TJ, Greenfield VY, Ostlund SB, Wassum KM (2016) Nucleus accumbens acetylcholine receptors modulate dopamine and motivation. Neuropsychopharmacol 41:2830-2838

39. Crowder TL, Ariwodola OJ, Weiner JL (2006) Kainate receptor activation potentiates GABAergic synaptic transmission in the nucleus accumbens core. Brain Res 1088:73-82

40. Corbit LH, Muir JL, Balleine BW (2001) The role of the nucleus accumbens in instrumental conditioning: evidence of a functional dissociation between accumbens core and shell. J Neurosci 21: 3251-3260

41. D'Ascenzo M, Fellin T, Terunuma M, Revilla-Sanchez R, Meaney DF, Auberson YP, Moss SJ, Haydon PG (2007) mGluR5 stimulates gliotransmission in the nucleus accumbens. Proc Natl Acad Sci U S A 104:1995-2000 
42. Diano S (2018) A new brain circuit in feeding control. Science 361(6397):29-30

43. Dossat AM, Diaz R, Gallo L, Panagos A, Kay K, Williams DL (2013) Nucleus accumbens GLP-1 receptors influence meal size and palatability. Am J Physiol Endocrinol Metab 304:E1314 E1320

44. Fattorini G, Antonucci F, Menna E, Matteoli M, Conti F (2015) Coexpression of VGLUT1 and VGAT sustains glutamate and GABA co-release and is regulated by activity in cortical neurons. J Cell Sci 128:1669-1673

45. Fattorini G, Ciriachi C, Conti F (2017) Few, activity-dependent, and ubiquitous VGLUT1/VGAT terminals in rat and mouse brain. Front Cell Neurosci 11:Article 229

46. Fellin T, D’Ascenzo M, Haydon PG (2007) Astrocytes control neuronal excitability in the nucleus accumbens. Sci World J 7: 89-97

47. Fernandes AR, Easton AC, De Souza Silva MA, Schumann G, Müller CP, Desrivières S (2012) Lentiviral-mediated gene delivery reveals distinct roles of nucleus accumbens dopamine D2 and D3 receptors in novelty- and light-induced locomotor activity. Eur J Neurosci 35:1344-1353

48. Fonseca F, Gratacòs M, Escaramís G, De Cid R, Martín-Santos R, Farré M, Estivill X, Torrens M (2014) ALDH5A1 variability in opioid dependent patients could influence response to methadone treatment. Eur Neuropsychopharmacol 24:420-424

49. Franke H, Krügel U, Grosche J, Heine C, Härtig W, Allgaier C, Illes P (2004) P2Y receptor expression on astrocytes in the nucleus accumbens of rats. Neurosci 127:431-441

50. Freund TF, Powell JF, Smith AD (1984) Tyrosine hydroxylaseimmunoreactive boutons in synaptic contact with identified striatonigral neurons, with particular reference to dendritic spines. Neurosci 13:1189-1215

51. Gavrilov N, Golyagina I, Brazhe A, Scimemi A, Turlapov V, Semyanov A (2018) Astrocytic coverage of dendritic spines, dendritic shafts, and axonal boutons in hippocampal neuropil. Front Cell Neurosci 12:Article 248

52. Girault JA (2012) Integrating neurotransmission in striatal medium spiny neurons. Adv Exp Med Biol 970:407-429

53. Goins EC, Bajic D (2018) Astrocytic hypertrophy in the rat ventral tegmental area following chronic morphine differs with age. J Neurol Neurorehabilit Res 3:14-21

54. Gomes FV, Llorente R, Del Bel EA, Viveros MP, López-Gallardo M, Guimarães FS (2015) Decreased glial reactivity could be involved in the antipsychotic-like effect of cannabidiol. Schizophr Res 164:155-163

55. Goodman T, Hajihosseini MK (2015) Hypothalamic tanycytes masters and servants of metabolic, neuroendocrine, and neurogenic functions. Front Neurosci 9:article 387

56. Gordon GRJ, Iremonger KJ, Kantevari S, Ellis-Davies GRC, Brian A, MacVicar BA, Bains JS (2009) Astrocyte mediated distributed plasticity at hypothalamic glutamate synapses. Neuron 64:391-403

57. Goto Y, Grace AA (2008) Limbic and cortical information processing in the nucleus accumbens. Trends Neurosci 31:552-558

58. Gracy KN, Pickel VM (1996) Ultrastructural immunocytochemical localization of the N-methyl-D-aspartate receptor and tyrosine hydroxylase in the shell of the rat nucleus accumbens. Brain Res 739:169-181

59. Griebel G, Holsboer F (2012) Neuropeptide receptor ligands as drugs for psychiatric diseases: the end of the beginning? Nature Rev Drug Discovery 11:462-478

60. Griffin WC 3rd, Haun HL, Hazelbaker CL, Ramachandra VS, Becker HC (2014) Increased extracellular glutamate in the nucleus accumbens promotes excessive ethanol drinking in ethanol dependent mice. Neuropsychopharmacol 39:707-717
61. Groenewegen HJ, Wright CI, Beijer AV, Voorn P (1999) Convergence and segregation of ventral striatal inputs and outputs. Ann N Y Acad Sci 877:49-63

62. Groves PM, Linder JC, Young SJ (1994) 5-hydroxydopaminelabeled dopaminergic axons: three-dimensional reconstructions of axons, synapses and postsynaptic targets in rat neostriatum. Neurosci 58:593-604

63. Halassa MM, Fellin T, Takano H, Dong J-H, Haydon PG (2007) Synaptic islands defined by the territory of a single astrocyte. J Neurosci 27:6473-6477

64. Hall J, Parkinson JA, Connor TM, Dickinson A, Everitt BJ (2001) Involvement of the central nucleus of the amygdala and nucleus accumbens core in mediating Pavlovian influences on instrumental behaviour. Eur J Neurosci 13:1984-1992

65. He W, Miao FJ, Lin DC, Schwandner RT, Wang Z, Gao J, Chen JL, Tian $\mathrm{H}$ et al (2004) Citric acid cycle intermediates as ligands for orphan G-protein-coupled receptors. Nature 429(6988):188193

66. Demos KE, Heatherton TF, Kelley WM (2012) Individual differences in nucleus accumbens activity to food and sexual images predict weight gain and sexual behavior. J Neurosci 32:55495552

67. Heimer L, Alheid GF, de Olmos JS, Groenewegen HJ, Haber SN, Harlan RE, Zahm DS (1997) The accumbens: beyond the coreshell dichotomy. J Neuropsychiat Clin Neurosci 9:354-381

68. Héja L, Barabás P, Nyitrai G, Kékesi KA, Lasztóczi B, Tőke O, Tárkányi G, Madsen K et al (2009) Glutamate uptake triggers transporter-mediated GABA release from astrocytes. PLoS One 4:e7153-e7112

69. Héja L, Nyitrai G, Kékesi O, Dobolyi A, Szabó P, Fiáth R, Ulbert I, Pál-Szenthe B et al (2012) Astrocytes convert network excitation to tonic inhibition of neurons. BMC Biol 10:26

70. Héja L (2014) Astrocytic target mechanisms in epilepsy. Curr Med Chem 21:755-763

71. Heller JP, Rusakov DA (2015) Morphological plasticity of astroglia: understanding synaptic microenvironment. Glia 63: 2133-2151

72. Hernandez PJ, Sadeghian K, Kelley AE (2002) Early consolidation of instrumental learning requires protein synthesis in the nucleus accumbens. Nature Neurosci 5:1327-1331

73. Higuera-Matas A, Montoya LG, Coria MS, Miguens M, GarciaLecumberri C, Ambrosio E (2011) Differential gene expression in the nucleus accumbens and frontal cortex of Lewis and Fischer 344 rats relevant to drug addiction. Curr Neuropharmacol 9:143150

74. Ho MC Cherng CG, Tsai YPChiang CY, Chuang JY, Kao SF, Yu L (2009) Chronic treatment with monoamine oxidase-B inhibitors decreases cocaine reward in mice. Psychopharmacology 205:141149

75. Hopf FW (2017) Do specific NMDA receptor subunits act as gateways for addictive behaviors? Genes Brain Behav 16:118138

76. Horovitz O, Richter-Levin G (2015) Dorsal periaqueductal gray simultaneously modulates ventral subiculum induced-plasticity in the basolateral amygdala and the nucleus accumbens. Front Behavioral Neurosci 9:article 53

77. Huang CC, Liang YC, Lee CC, Hsu KS (2015) Cocaine withdrawal impairs mGlur5-dependent long-term depression in nucleus accumbens shell neurons of both direct and indirect pathways. Mol Neurobiol 52:1223-1233

78. Huang H, Acuna-Goycolea C, Li Y, Cheng HM, Obrietan K, van den Pol AN (2007) Cannabinoids excite hypothalamic melaninconcentrating hormone but inhibit hypocretin/orexin neurons: implications for cannabinoid actions on food intake and cognitive arousal. J Neurosci 27:4870-4881 
79. Hyman SE, Malenka RC, Nestler EJ (2006) Neural mechanisms of addiction: the role of reward-related learning and memory. Annu Rev Neurosci 29:565-598

80. Iacopetta D, Madeo M, Tasco G, Carrisi C, Curcio R, Martello E, Casadio R, Capobianco L et al (2011) A novel subfamily of mitochondrial dicarboxylate carriers from Drosophila melanogaster: biochemical and computational studies. BBA Bioenerg 1807: 251-261

81. Ikemoto S, Bonci A (2014) Neurocircuitry of drug reward. Neuropharmacol 76. https://doi.org/10.1016/j.neuropharm.2013. 04.031

82. Ikemoto S, Yang C, Tan A (2015) Basal ganglia circuit loops, dopamine and motivation: a review and enquiry. Behav Brain Res 290:17-31

83. Ikemoto S (2007) Dopamine reward circuitry: two projection systems from the ventral midbrain to the nucleus accumbensolfactory tubercle complex. Brain Res Rev 56:27-78

84. Iverson TM (2013) Catalytic mechanisms of complex II enzymes: a structural perspective. Biochim Biophys Acta 1827:648-657

85. Kalenscher T, Lansink CS, Lankelma JV, Pennartz CM (2010) Reward-associated gamma oscillations in ventral striatum are regionally differentiated and modulate local firing activity. J Neurophysiol 103:1658-1672

86. Kardos J, Szabó Z, Héja L (2016) Framing neuro-glia coupling in antiepileptic drug design. J Med Chem 59:777-787

87. Kardos J, Héja L, Jemnitz K, Kovács R, Palkovits M (2017) The nature of early astroglial protection-fast activation and signaling. Prog Neurobiol 153:86-99

88. Kasanetz F, Deroche-Gamonet V, Berson N, Balado E, Lafourcade M, Manzoni O, Vincenzo Piazza P (2010) Transition to addiction is associated with a persistent impairment in synaptic plasticity. Science 328(5986):1709-1712

89. Kékesi O, Ioja E, Szabó Z, Kardos J, Héja L (2014) Recurrent seizure-like events are associated with coupled astroglial synchronization. Front Cellular Neurosci 9:paper 215

90. Kelley AE, Baldo BA, Pratt WE, Will MJ (2005) Corticostriatalhypothalamic circuitry and food motivation: integration of energy, action and reward. Physiol Behav 86:773-795

91. Kelley AE, Smith-Roe SL, Holahan MR (1997) Responsereinforcement learning is dependent on $N$-methyl-D-aspartate receptor activation in the nucleus accumbens core. Proc Natl Acad Sci U S A 94:12174-12179

92. Kelz MB, Chen J, W a CJ, Whisler K, Gilden L, Beckmann AM, Steffen C, Zhang YJ et al (1999) Expression of the transcription factor deltaFosB in the brain controls sensitivity to cocaine. Nature 401:272-276

93. Khakh BS, Beaumont V, Cachope R, Munoz-Sanjuan I, Goldman SA, Grantyn R (2017) Unravelling and exploiting astrocyte dysfunction in Huntington's disease. Trends Neurosci 40:422-437

94. Kim R, Healey KL, Sepulveda-Orengo MT, Reissner KJ (2017) Astroglial correlates of neuropsychiatric disease: from astrocytopathy to astrogliosis. Prog Neuro-Psychopharmacol Biol Psychiatry

95. Kircher DM, Aziz H, Mangieri RA, Morrisett RA (2019) Ethanol experience enhances glutamatergic ventral hippocampal inputs to D1 receptor-expressing medium spiny neurons in the nucleus accumbens shell. J Neurosci. https://doi.org/10.1523/JNEUROSCI. 3051-18.2019

96. Kirischuk S, Héja L, Kardos J, Billups B (2016) Astrocyte sodium signaling and the regulation of neurotransmission. Glia 64:16551666

97. Kirischuk S, Parpura V, Verkhratsky A (2012) Sodium dynamics: another key to astroglial excitability? Trends Neurosci 2012(35): 497-506

98. Kittner H, Krügel U, Hoffmann E, Illés P (2004) Modulation of feeding behaviour by blocking purinergic receptors in the rat nucleus accumbens: a combined microdialysis, electroencephalographic and behavioural study. Eur J Neurosci 19:396-404

99. Koch M (2017) Cannabinoid receptor signaling in central regulation of feeding behavior: a mini-review. Front Neurosci 11:293

100. Koós T, Tecuapetla F, Tepper JM (2011) Glutamatergic signaling by midbrain dopaminergic neurons: recent insights from optogenetic, molecular and behavioral studies. Curr Opin Neurobiol 21:393-401

101. Koós T, Tepper JM (1999) Inhibitory control of neostriatal projection neurons by GABAergic interneurons. Nat Neurosci 2:467472

102. Kucera R, Bouskila J, Elkrief L, Fink-Jensen A, Palmour R, Bouchard JF, Ptito M (2018) Expression and localization of CB1R, NAPE-PLD, and FAAH in the velvet monkey nucleus accumbens. Sci Rep 8:8689

103. Kupchik YM, Moussawi K, Tang XC, Wang X, Kalivas BC, Kolokithas R, Ogburn KB, Kalivas PW (2012) The effect of Nacetylcysteine in the nucleus accumbens on neurotransmission and relapse to cocaine. Biol Psychiatry 71:978-986

104. Lansink CS, Goltstein PM, Lankelma JV, Pennartz CM (2010) Fast-spiking interneurons of the rat ventral striatum: temporal coordination of activity with principal cells and responsiveness to reward. Eur J Neurosci 32:494-508

105. Lape R, Dani JA (2004) Complex response to afferent excitatory bursts by nucleus accumbens medium spiny projection neurons. J Neurophysiol 92:1276-1284

106. Lau J, Herzog H (2014) CART in the regulation of appetite and energy homeostasis. Front Neurosci 8:Article 313

107. Lauer M, Heinsen H (1996) Cytoarchitectonics of the human nucleus accumbens. J Hirnforsch 37:243-254

108. Lee BR, Dong Y (2011) Cocaine-induced metaplasticity in the nucleus accumbens: silent synapse and beyond. Neuropharmacol 61:1060-1069

109. Lee BR, Ma YY, Huang YH, Wang X, Otaka M, Ishikawa M, Neumann PA, Graziane NM et al (2013) Maturation of silent synapses in amygdala-accumbens projection contributes to incubation of cocaine craving. Nat Neurosci 16:1644-1651

110. Lee M-C, Yasuda R, Ehlers MD (2010) Metaplasticity at single glutamatergic synapses. Neuron 66:859-870

111. Li X, Peng XQ, Jordan CJ, Li J, Bi GH, He Y, Yang HJ, Zhang HY et al (2018) mGluR5 antagonism inhibits cocaine reinforcement and relapse by elevation of extracellular glutamate in the nucleus accumbens via a CB1 receptor mechanism. Sci Rep 8:3686

112. Ligorio M, Descarries L, Warren RA (2009) Cholinergic innervation and thalamic input in rat nucleus accumbens. J Chem Neuroanat 37:3345

113. Lin K-Y, Cherng CG, Yang F-R, Lin L-C, Lu R-B, Yu L (2011) Memantine abolishes the formation of cocaine-induced conditioned place preference possibly via its IL-6-modulating effect in medial prefrontal cortex. Behav Brain Res 220:126-131

114. Ling H, Kovács GG, Vonsattel JPG, Davey K, Mok KY, Hardy J, Morris HR, Warner TT et al (2016) Astroglyopathy predominate the earliest stage of corticobasal degeneration pathology. Brain 139:3237-3252

115. Liu B, Teschemacher AG, Kasparov S (2017) Astroglia as a cellular target for neuroprotection and treatment of neuro-psychiatric disorders. Glia 65:1205-1226

116. Lüscher C, Malenka RC (2011) Drug-evoked synaptic plasticity in addiction: from molecular changes to circuit remodeling. Neuron 69:650-663

117. Luo SX, Huang J, Li Q, Mohammad H, Lee CY, Krishna K, Kok AM, Tan YL et al (2018) Regulation of feeding by somatostatin neurons in the tuberal nucleus. Science 361(6397):76-81

118. MacDonald CL, Silva GA (2013) A positive feedback cell signalling nucleation model of astrocyte dynamics. Front Neuroengin 6: article 4 
119. Mahler SV, Smith KS, Berridge KC (2007) Endocannabinoid hedonic hotspot for sensory pleasure: anandamide in nucleus accumbens shell enhances 'liking' of a sweet reward. Neuropsychopharmacol 32: 2267-2278

120. Malaspina P, Roullet JB, Pearl PL, Ainslie GR, Vogel KR, Gibson KM (2016) Succinic semialdehyde dehydrogenase deficiency (SSADHD): pathophysiological complexity and multifactorial trait associations in a rare monogenic disorder of GABA metabolism. Neurochem Int 2016(99):72-84

121. Manzoni O, Michel JM, Bockaert J (1997) Metabotropic glutamate receptors in the rat nucleus accumbens. Eur J Neurosci 9: $1514-1523$

122. Mariotti L, Losi G, Lia A, Melone M, Chiavegato A, GómezGonzalo M, Sessolo M, Bovetti S et al (2018) Interneuronspecific signaling evokes distinctive somatostatin-mediated responses in adult cortical astrocytes. Nat Commun 9:82

123. Melone M, Ciriachi C, Pietrobon D, Conti F (2018) Heterogeneity of astrocytic and neuronal GLT-1 at cortical excitatory synapses, as revealed by its colocalization with $\mathrm{Na}^{+} / \mathrm{K}^{+}$-ATPase $\alpha$ isoforms. Cereb Cortex:1-20

124. Mills EL, Kelly B, Logan A, Costa ASH, Varma M, Bryant CE, Tourlomousis P, Däbritz JHM et al (2016) Repurposing mitochondria from ATP production to ROS generation drives a proinflammatory phenotype in macrophages that depends on succinate oxidation by complex II. Cell 167:457-470

125. Min R, Santello M, Nevian T (2012) The computational power of astrocyte mediated synaptic plasticity. Front Computational Neurosci 6:article93

126. Mishra D, Pena-Bravo JI, Leong K-C, Lavin A, Reichel CM (2017) Methamphetamine self-administration modulates glutamate neurophysiology. Brain Struct Funct 222:2031-2039

127. Mogenson GJ, Jones DL, Yim CY (1980) From motivation to action: functional interface between the limbic system and the motor system. Prog Neurobiol 14:69-97

128. Molnár T, Barabás P, Héja L, Fekete EK, Lasztóczi B, Szabó P, Nyitrai G, Simon-Trompler E et al (2008a) GammaHydroxybutyrate binds to the synaptic site recognizing succinate monocarboxylate: a new hypothesis on astrocyte-neuron interaction via the protonation of succinate. J Neurosci Res 6:1566-1576

129. Molnár T, Dobolyi A, Nyitrai G, Barabás P, Héja L, Emri Z, Palkovits M, Kardos J (2011a) Calcium signals in the nucleus accumbens: activation of astrocytes by ATP and succinate. BMC Neurosci 12:96

130. Molnár T, Fekete EK, Kardos J, Simon-Trompler E, Palkovits M, Emri Z (2006) Metabolic GHB precursor succinate binds to gamma-hydroxybutyrate receptors: characterization of human basal ganglia areas nucleus accumbens and globus pallidus. J Neurosci Res 84:27-36

131. Molnár T, Héja L, Emri Z, Simon A, Nyitrai G, Pál I, Kardos J (2011b) Activation of astroglial calcium signaling by endogenous metabolites succinate and gamma-hydroxybutyrate in the nucleus accumbens. Front Neuroenerg 3:7

132. Molnár T, Károly AI, Nyitrai G, Emri Z (2009) Gammahydroxybutyrate $(\mathrm{GHB})$ induces $\mathrm{GABA}(\mathrm{B})$ receptor independent intracellular $\mathrm{Ca}^{2+}$ transients in astrocytes, but has no effect on $\mathrm{GHB}$ or $\mathrm{GABA}(\mathrm{B})$ receptors of medium spiny neurons in the nucleus accumbens. Neurosci 162:268-281

133. Molnár T, Visy J, Simon A, Moldvai I, Temesvári-Major E, Dörnyei G, Fekete EK, Kardos J (2008b) Validation of highaffinity binding sites for succinic acid through distinguishable binding of gamma-hydroxybutyric acid receptor-specific NCS 382 antipodes. Bioorg Med Chem Lett 18:6290-6292

134. Morrison CD (2009) Leptin signaling in brain: a link between nutrition and cognition? Biochim Biophys Acta 1792:401-408

135. Murphy-Royal C, Dupuis JP, Varela JA, Panatier A, Pinson B, Baufreton J, Groc L, Oliet SHR (2015) Surface diffusion of astrocytic glutamate transporters shapes synaptic transmission. Nat Neurosci 18:219-226

136. Nauta WJ, Smith GP, Faull RL, Domesick VB (1978) Efferent connections and nigral afferents of the nucleus accumbens septi in the rat. Neurosci 3:385-401

137. Neto LL, Oliveira E, Correia F, Ferreira AG (2008) The human nucleus accumbens: where is it? A stereotactic, anatomical and magnetic resonance imaging study. Neuromodulation: Technology at the neural interface 11:14-22

138. Nie H, Rewal M, Gill TM, Ron D, Janak PH (2011) Extrasynaptic $\delta$-containing $\mathrm{GABA}_{\mathrm{A}}$ receptors in the nucleus accumbens dorsomedial shell contribute to alcohol intake. Proc Natl Acad Sci U S A 108:4459-4464

139. Nie R, Stark S, Symersky J, Kaplan RS, Lu M (2017) Structure and function of the divalent anion/ $\mathrm{Na}^{+}$symporter from Vibrio cholerae and a humanized variant. Nat Commun 8:15009

140. Nimmerjahn A, Mukamel EA, Schnitzer MJ (2009) Motor behavior activates Bergmann glial networks. Neuron 62:400

141. Ntamati NR, Lüscher C (2016) VTA projection neurons releasing gaba and glutamate in the dentate gyrus. eNeuro 3(4)

142. O'Donnell P, Grace AA (1995) Synaptic interactions among excitatory afferents to nucleus accumbens neurons: hippocampal gating of prefrontal cortical input. J Neurosci 15:3622-3639

143. O'Donnell P, Greene J, Pabello N, Lewis BL, Grace AA (1999) Modulation of cell firing in the nucleus accumbens. Ann N Y Acad Sci 877:157-175

144. O'Donovan SM, Sullivan CR, McCullumsmith RE (2017) The role of glutamate transporters in the pathophysiology of neuropsychiatric disorders. NPJ Schizophr 3:32

145. O'Doherty J, Dayan P, Schultz J, Deichmann R, Friston K, Dolan RJ (2004) Dissociable roles of ventral and dorsal striatum in instrumental conditioning. Science 304:452-454

146. Ohgake S, Hashimoto K, Shimizu E, Koizumi H, Okamura N, Koike K, Matsuzawa D, Sekine Y et al (2005) Functional polymorphism of the NQO2 gene is associated with methamphetamine psychosis. Addict Biol 10:145-148

147. Ostroumov A, Dani JA (2018) Inhibitory plasticity of mesocorticolimbic circuits in addiction and mental illness. Trend Neurosci

148. Pacher P, Batkai S, Kunos G (2006) The endocannabinoid system as an emerging target of pharmacotherapy. Pharmacol Rev 58: $389-462$

149. Pál I, Nyitrai G, Kardos J, Héja L (2013) Neuronal and astroglial correlates underlying spatiotemporal intrinsic optical signal in the rat hippocampal slice. PLoS One 8:e57694

150. Palmieri L, Palmieri F, Runswick MJ, Walker JE (1996) Identification by bacterial expression and functional reconstitution of the yeast genomic sequence encoding the mitochondrial dicarboxylate carrier protein. FEBS Lett 399:299-302

151. Pannasch U, Vargová L, Reingruber J, Ezan P, Holcman D, Giaume C, Syková E, Rouach N (2011) Astroglial networks scale synaptic activity and plasticity. Proc Natl Acad Sci U S A 108: 8467-8472

152. Parkin GM, Udawela M, Gibbons A, Dean B (2018) Glutamate transporters, EAAT1 and EAAT2, are potentially important in the pathophysiology and treatment of schizophrenia and affective disorders. World J Psychiatry 8:51-63

153. Parri HR, Crunelli V (2001) Pacemaker calcium oscillations in thalamic astrocytes in situ. Neuroreport 12:3897-3900

154. Pennartz CMA, Groenewegen HJ, Lopes Da Silva FH (1994) The nucleus accumbens as a complex of functionally distinct neuronal ensembles: an integration of behavioural, electrophysiological and anatomical data. Prog Neurobiol 42:719-761

155. Perez-Alvarez A, Navarrete M, Covelo A, Martin ED, Araque A (2014) Structural and functional plasticity of astrocyte processes and dendritic spine interactions. J Neurosci 34:12738-12744 
156. Perreault ML, Fan T, Alijaniaram M, O’Dowd BF, George SR (2012) Dopamine D1-D2 receptor heteromer in dual phenotype GABA/glutamate-coexpressing striatal medium spiny neurons: regulation of BDNF, GAD67 and VGLUT1/2. PLoS One 7: e33348

157. Peters J, LaLumiere RT, Kalivas PW (2008) Infralimbic prefrontal cortex is responsible for inhibiting cocaine seeking in extinguished rats. J Neurosci 28:6046-6053

158. Picard M, McManus MJ, Gray JD, Nasca C, Moffat C, Kopinski PK, Seifert EL, McEwen BS et al (2015) Mitochondrial functions modulate neuroendocrine, metabolic, inflammatory, and transcriptional responses to acute psychological stress. Proc Natl Acad Sci U S A 112:E6614-E6623

159. Picklo MJ Sr, Olson SJ, Hayes JD, Markesbery WR, Montine TJ (2001) Elevation of AKR7A2 (succinic semialdehyde reductase) in neurodegenerative disease. Brain Res 916:229-238

160. Pirttimaki TM, Hall S, Parri HR (2011) Sustained neuronal activity generated by glial plasticity. J Neurosci 31:7637-7647

161. Pirttimaki TM, Sims RE, Saunders G, Antonio SA, Codadu NK, Parri HR (2017) Astrocyte-mediated neuronal synchronization properties revealed by false gliotransmitter release. J Neurosci 37:9859-9870

162. Poskanzer KE, Yuste R (2016) Astrocytes regulate cortical state switching in vivo. Proc Natl Acad Sci 113:E2675-E2684

163. Qi J, Zhang S, Wang HL, Barker DJ, Miranda-Barrientos J, Morales M (2016) VTA glutamatergic inputs to nucleus accumbens drive aversion by acting on GABAergic interneurons. Nat Neurosci 19:725-733

164. Rada P, Tucci S, Murzi E, Hernández L (1997) Extracellular glutamate increases in the lateral hypothalamus and decreases in the nucleus accumbens during feeding. Brain Res 768:338-340

165. Raimondo JV, Richards BA, Woodin MA (2017) Neuronal chloride and excitability - the big impact of small changes. Curr Opin Neurobiol 43:35-42

166. Rexen Ulven E, Trauelsen M, Brvar M, Lückmann M, Bielefeldt LØ, Jensen LKI, Schwartz TW, Frimurer TM (2018) Structureactivity investigations and optimisations of nonmetabolite agonists for the succinate receptor 1. Sci Rep 8:10010

167. Reynolds SM, Berridge KC (2003) Glutamate motivational ensembles in nucleus accumbens: rostrocaudal shell gradients of fear and feeding. Eur J Neurosci 17:2187-2200

168. Reynolds SM, Berridge KC (2002) Positive and negative motivation in nucleus accumbens shell: bivalent rostrocaudal gradients for GABA-elicited eating, taste "liking"/“disliking" reactions, place preference/avoidance and fear. J Neurosci 22:7308-7320

169. Ribeiro EA, Nectow AR, Pomeranz LE, Ekstrand MI, Koo JW, Nestler EJ (2019) Viral labeling of neurons synaptically connected to nucleus accumbens somatostatin interneurons. PLoS One 14: $\mathrm{e} 0213476$

170. Richard JM, Berridge KC (2011) Metabotropic glutamate receptor blockade in nucleus accumbens shell shifts affective valence toward fear and displeasure. Eur J Neurosci 33:736-747

171. Robbins TW, Everitt BJ (2007) A role for mesencephalic dopamine in activation: commentary on Berridge (2006). Psychopharmacol (Berl) 191:433-437

172. Robertson JM (2018) The gliocentric brain. Int J Mol Sci 10:3033

173. Rohde K, Federbusch M, Horstmann A, Keller M, Villringer A, Stumvoll M, Tönjes A, Kovacs P et al (2015) Genetic variants in $A K R 1 B 10$ associate with human eating behavior. BMC Genet 16: 31

174. Rose CR, Chatton J-Y (2016) Astrocyte sodium signaling and neuro-metabolic coupling in the brain. Neurosci 2016(323):121134

175. Rubic T, Lametschwandtner G, Jost S, Hinteregger S, Kund J, Carballido-Perrig N, Schwärzler C, Junt T et al (2008)
Triggering the succinate receptor GPR91 on dendritic cells enhances immunity. Nat Immunol 9:1261-1269

176. Russo SJ, Dietz DM, Dumitriu D, Malenka RC, Nestler EJ (2010) The addicted synapse: mechanisms of synaptic and structural plasticity in nucleus accumbens. Trends Neurosci 33:267-276

177. Russo SJ, Wilkinson MB, Mazei-Robison MS, Dietz DM, Maze I, Krishnan V, Renthal W, Graham A et al (2009) Nuclear factor kappa $\mathrm{B}$ signaling regulates neuronal morphology and cocaine reward. J Neurosci 29:3529-3537

178. Salamone JD, Correa M, Mingote SM, Weber SM (2005) Beyond the reward hypothesis: alternative functions of nucleus accumbens dopamine. Curr Op Pharmacol 5:34-41

179. Sapieha P, Sirinyan M, Hamel D, Zaniolo K, Joyal JS, Cho JH, Honoré JC, Kermorvant-Duchemin E et al (2008) The succinate receptor GPR91 in neurons has a major role in retinal angiogenesis. Nat Med 14:1067-1076

180. Schultz W (2010) Dopamine signals for reward value and risk: basic and recent data. Behav Brain Funct 2010(6):24

181. Scofield MD, Heinsbroek JA, Gipson CD, Kupchik YM, Spencer S, Smith ACW, Roberts-Wolfe D, Kalivas PW (2016a) The nucleus accumbens: mechanisms of addiction across drug classes reflect the importance of glutamate homeostasis. Pharmacol Rev 68:816-871

182. Scofield MD, Boger HA, Smith RJ, Li H, Haydon PG, Kalivas PW (2015) Gq-DREADD selectively initiates glial glutamate release and inhibits cue-induced cocaine seeking. Biol Psychiatry 78:441-451

183. Scofield MD, Li H, Siemsen BM, Healey KL, Tran PK, Woronoff N, Boger HA, Kalivas PW et al (2016b) Cocaine selfadministration and extinction leads to reduced glial fibrillary acidic protein expression and morphometric features of astrocytes in the nucleus accumbens core. Biol Psychiatry 80:207-215

184. Scofield MD (2018) Exploring the role of astroglial glutamate release and association with synapses in neuronal function and behavior. Biol Psychiatry 84:778-786

185. Segovia KN, Correa M, Lennington JB, Conover JC, Salamone JD (2012) Changes in nucleus accumbens and neostriatal c-Fos and DARPP-32 immunoreactivity during different stages of foodreinforced instrumental training. Eur J Neurosci 35:1354-1367

186. Sellings LH, McQuade LE, Claske PB (2006) Evidence for multiple sites within rat ventral striatum mediating cocaineconditioned place preference and locomotor activation. J Pharmacol Exp Ther 317:1178-1187

187. Sepulveda-Orengo MT, Healey KL, Kim R, Auriemma AC, Rojas J, Woronoff N, Hyppolite R, Reissner KJ (2018) Riluzole impairs cocaine reinstatement and restores adaptations in intrinsic excitability and GLT-1 expression. Neuropsychopharmacol 43:12121223

188. Sesack SR, Piskel VM (1990) In the rat medial nucleus accumbens, hippocampal and catecholaminergic terminals converge on spiny neurons and are in apposition to each other. Brain Res 527: 266-279

189. Shabel SJ, Proulx CD, Piriz J, Malinow R (2014) Mood regulation. GABA/glutamate co-release controls habenula output and is modified by antidepressant treatment. Science 345:1494-1498

190. Shin R, Ikemoto S (2010) Administration of the $\mathrm{GABA}_{\mathrm{A}}$ receptor antagonist picrotoxin into rat supramammillary nucleus induces cFos in reward-related brain structures. Supramammillary picrotoxin and c-Fos expression. BMC Neurosci 11:101

191. Shin S, Kwon O, Kang JI, Kwon S, Oh S, Choi J, Kim CH, Kim DG (2015) mGluR5 in the nucleus accumbens is critical for promoting resilience to chronic stress. Nat Neurosci 18:1017-2104

192. Shirayama Y, Chaki S (2006) Neurochemistry of the nucleus accumbens and its relevance to depression and antidepressant action in rodents. Curr Neuropharmacol 4:277-291 
193. Sims RE, Butcher JB, Parri R, Glazewski S (2015) Astrocyte and neuronal plasticity in the somatosensory system. Neural Plasticity: Article ID 732014

194. Smith Y, Kieval J, Couceyro PR, Kuhar MJ (1999) CART peptideimmunoreactive neurones in the nucleus accumbens in monkeys: ultrastructural analysis, colocalization studies, and synaptic interactions with dopaminergic afferents. J Comp Neurol 407:491-511

195. Smith-Roe SL, Kelley AE (2000) Coincident activation of NMDA and dopamine $\mathrm{D}_{1}$ receptors within the nucleus accumbens core is required for appetitive instrumental learning. J Neurosci 20:77377742

196. Staley JK, Mash DC (1996) Adaptive increase in D3 dopamine receptors in the brain reward circuits of human cocain fatalities. J Neurosci 16:6100-6106

197. Stefanik MT, Kupchik YM, Kalivas PW (2016) Optogenetic inhibition of cortical afferents in the nucleus accumbens simultaneously prevents cue-induced transient synaptic potentiation and cocaine-seeking behavior. Brain Struct Funct 221:1681-1689

198. Stratford TR, Wirtshafter D (2012) Effects of muscimol, amphetamine and DAMGO injected into the nucleus accumbens shell on food-reinforced lever pressing by undeprived rats. Pharmacol Biochem Behav 101:499-503

199. Sun F, Huo X, Zhai Y, Wang A, Xu J, Su D, Bartlam M, Rao Z (2005) Crystal structure of mitochondrial respiratory membrane protein complex II. Cell 121:1043-1057

200. Szabó Z, Héja L, Szalay G, Kékesi O, Füredi A, Szebényi K, Dobolyi Á, OrbÁn TI et al (2017) Extensive astrocyte synchronization advances neuronal coupling in slow wave activity in vivo. Sci Rep 7:paper 6018

201. Szárics E, Kovács R, Hajós F, Kardos J (2006) $\mathrm{Ca}^{2+}$ ion accumulation precedes formation of $\mathrm{O}_{2}^{-*}$ in isolated brain mitochondria. Neuroreport 17:1767-1771

202. Tannahill GM, Curtis AM, Adamik J, Palsson-McDermott EM, McGettrick AF, Goel G, Frezza C, Bernard NJ et al (2013) Succinate is a danger signal that induces IL- $1 \beta$ via HIF- $1 \alpha$. Nature 496(7444):238-242

203. Telzer EH (2016) Dopaminergic reward sensitivity can promote adolescent health: a new perspective on the mechanism of ventral striatum activation. Dev Cognitive Neurosci 17:57-67

204. Tessari M, Pilla M, Andreoli M, Hutcheson DM, Heidbreder CA (2004) Antagonism at metabotropic glutamate 5 receptors inhibits nicotine- and cocaine-taking behaviours and prevents nicotinetriggered relapse to nicotine-seeking. Eur J Pharmacol 499:121133

205. Testen A, Ali M, Sexton HG, Hodges S, Dubester K, Reissner KJ, Swartzwelder HS, Risher ML (2019) Region-specific differences in morphometric features and synaptic colocalization of astrocytes during development. Neurosci 400:98-109

206. Theodosis DT, Poulain DA, Oliet SH (2008) Activity-dependent structural and functional plasticity of astrocyte-neuron interactions. Physiol Rev 88:983-1008

207. Thiagarajan TC, Lindskog M, Malgaroli A, Tsien RW (2007) LTP and adaptation to inactivity: overlapping mechanisms and implications for metaplasticity. Neuropharmacol 52:156-175

208. Todtenkopf MS, Stellar JR, Williams EA, Zahm DS (2004) Differential distribution of parvalbumin immunoreactive neurons in the striatum of cocaine sensitized rats. Neuroscience 127:35-42

209. Torregrossa MM, MacDonald M, Stone KL, Lam TT, Nairn AC, Taylor JR (2019) Phosphoproteomic analysis of cocaine memory extinction and reconsolidation in the nucleus accumbens. Psychopharmacol 236:531-543

210. Trauelsen M, Ulven ER, Hjorth SA, Brvar MC, Frimurer TM, Schwartz TW (2017) Receptor structure-based discovery of nonmetabolite agonists for the succinate receptor GPR91. Mol Metabolism 6:1585-1596
211. Tretter L, Patócs A, Chinopoulos C (2016) Succinate, an intermediate in metabolism, signal transduction, ROS, hypoxia, and tumorigenesis. Biochim BiophysActa 1857:1086-1101

212. Turner BD, Rook JM, Lindsley CW, Conn PJ, Grueter BA (2018) mGlu(1) and mGlu(5) modulate distinct excitatory inputs to the nucleus accumbens shell. Neuropsychopharmacol 43:2075-2082

213. Unichenko P, Dvorzhak A, Kirischuk S (2013) Transportermediated replacement of extracellular glutamate for GABA in the developing murine neocortex. Eur J Neurosci 38:3580-3588

214. Urstadt KR, Stanley BG (2015) Direct hypothalamic and indirect trans-pallidal, trans-thalamic, or trans-septal control of accumbens signaling and their roles in food intake. Front Systems Neruosci 9: article 8

215. Usuda I, Tanaka K, Chiba T (1998) Efferent projections of the nucleus accumbens in the rat with special reference to subdivision of the nucleus: biotinylated dextran amine study. Brain Res 797: 73-93

216. Verkhratsky A, Nedergaard M (2016) Physiology of astroglia. Physiological Rev 98:239-389

217. Vicentic A, Jones DC (2007) The CART (cocaine- and amphetamine-regulated transcript) system in appetite and drug addiction. J Pharmacol Exp Ther 320:499-506

218. Virk MS, Sagi Y, Medrihan L, Leung J, Kaplitt MG, Greengard P (2016) Opposing roles for serotonin in cholinergic neurons of the ventral and dorsal striatum. Proc Natl Acad Sci U S A 113:734 739

219. Vogel KR, Ainslie GR, McConnell A, Roullet J-B, Gibson KM (2018) Toxicologic/transport properties of NCS-382, a $\gamma$ hydroxybutyrate $(\mathrm{GHB})$ receptor ligand, in neuronal and epithelial cells: therapeutic implications for SSADH deficiency, a GABA metabolic disorder. Toxicol in Vitro 46:203-212

220. von Kügelgen I, Hoffmann K (2016) Pharmacology and structure of P2Y receptors. Neuropharmacol 104:50-61

221. Wakabayashi KT, Feja M, Baindur AN, Bruno MJ, Bhimani RV, Park J, Hausknecht K, Shen R-Y et al (2018) Chemogenetic activation of ventral tegmental area GABA neurons, but not mesoaccumbal GABA terminals, disrupts responding to rewardpredictive cues. Neuropsychopharmacology $0: 1-9$

222. Walsh JJ, Christoffel DJ, Heifets BD, Ben-Dor GA, Selimbeyoglu A, Hung LW, Deisseroth K, Malenka RC (2018) 5-HT release in nucleus accumbens rescues social deficits in mouse autism model. Nature 560(7720):589-594

223. Wang X, Gallegos DA, Pogorelov VM, O'Hare JK, Calakos N, Wetsel WC, West AE (2018) Parvalbumin interneurons of the mouse nucleus accumbens are required for amphetamineinduced locomotor sensitization and conditioned place preference. Neuropsychopharmacol 43:953-963

224. Wang Y, Hsuchou H, He Y, Kastin AJ, Pan W (2015) Role of astrocytes in leptin signaling. J Mol Neurosci 56:829-839

225. Warner-Schmidt JL, Schmidt EF, Marshall JJ, Rubin AJ, ArangoLievano M, Kaplitt MG, Ibanez-Tallon I, Heintz N et al (2012) Cholinergic interneurons in the nucleus accumbens regulate depression-like behavior. Proc Natl Acad Sci 109:11360-11365

226. Warren BL, Whitaker LR (2018) Parvalbumin-expressing neurons in the nucleus accumbens: a new player in amphetamine sensitization and reward. Neuropsychopharmacol 43:929-930

227. White LE, Hodges HD, Carnes KM, price JL, Dubinsky JM (1994) Colocalization of excitatory and inhibitory neurotransmitter markers in striatal projection neurons in the rat. J Comp Neurol 339:328-340

228. Wilson CJ, Groves PM, Kitai ST, Linder JC (1983) Threedimensional structure of dendritic spines in the rat neostriatum. J Neurosci 3:383-388

229. Wilson CS, Mongin AA (2018) The signaling role for chloride in the bidirectional communication between neurons and astrocytes. Neurosci Lett https://doi.org/10.1016/j.neulet.2018.01.012 
230. Wise RA, McDevitt RA (2018) Drive and reinforcement circuitry in the brain: origins, neurotransmitters, and projection fields. Neuropsychopharmacol 43:680-689

231. Wójtowicz AM, Dvorzhak A, Semtner M, Grantyn R (2013) Reduced tonic inhibition in striatal output neurons from Huntington mice due to loss of astrocytic GABA release through GAT-3. Front Neural Circ 7:188

232. Wood J, Ahmari SE (2015) A framework for understanding the emerging role of corticolimbic-ventral striatal networks in OCDassociated repetitive behaviors. Front Systems Neursci 9:article 171

233. Xi Z-X, Baker DA, Shen H, Carson DS, Kalivas PW (2002) Group II metabotropic glutamate receptors modulate extracellular glutamate in the nucleus accumbens. J Pharmacol Exp Ther 300: $162-171$

234. Xin W, Schuebel KE, K-w J, Cimbro R, De Biase LM, Goldman D, Bonci A (2019) Ventral midbrain astrocytes display unique physiological features and sensitivity to dopamine D2 receptor signaling. Neuropsychopharmacol 44:344-355

235. Yin HH, Ostlund SB, Balleine BW (2008) Reward-guided learning beyond dopamine in the nucleus accumbens: the integrative functions of cortico-basal ganglia networks. Eur J Neurosci 28: $1437-1448$

236. Yoon B-E, Woo J, Chun Y-E, Chun H, Jo S, Bae JY, An H, Min JO et al (2014) Glial GABA, synthesized by monoamine oxidase B mediates tonic inhibition. J Physiol 592(22):4951-4968

237. Záborszky L, Alheid GF, Beinfield MC, Eiden LE, Heimer L, Palkovits M (1985) Cholecystokinin innervation of the ventral striatum: a morphological and radioimmunological study. Neuroscience 14:427-453
238. Zahm DS (2008) Accumbens in a functional-anatomical context. In: David HN (ed) The nuceleus accumbens: neurotransmitters \& related behaviours, pp. 1-36

239. Zahm DS (1992) An electron microscopic morphometric comparison of tyrosine hydroxylase immunoreactive innervation in the neostriatum and the nucleus accumbens core and shell. Brain Res 575:341-346

240. Zahm DS (2000) An integrative neuroanatomical perspective on some subcortical substrates of adaptive responding with emphasis on the nucleus accumbens. Neurosci Biobehav Rev 24:85-105

241. Zahm DS (1999) Functional-anatomical implications of the nucleus accumbens core and shell subterritories. Ann N Y Acad Sci 877:113-128

242. Zhang D, Gao Z-G, Zhang K, Kiselev E, Crane S, Wang J, Paoletta S, Yi C et al (2015) Two disparate ligand binding sites in the human P2Y1 receptor. Nature 520(7547):317-321

243. Zhang X, Lee TH, Xiong X, Chen Q, Davidson C, Wetsel WC, Ellinwood EH (2006) Methamphetamine induces long-term changes in $\mathrm{GABA}_{\mathrm{A}}$ receptor alpha2 subunit and GAD67 expression. Biochem Biophys Res Commun 351:300-305

244. Zhu X, Ottenheimer D, DiLeone RJ (2016) Activity of D1/2 receptor expressing neurons in the nucleus accumbens regulates running, locomotion, and food intake. Front Behavioral Neurosci 10:article 66

Publisher's Note Springer Nature remains neutral with regard to jurisdictional claims in published maps and institutional affiliations. 